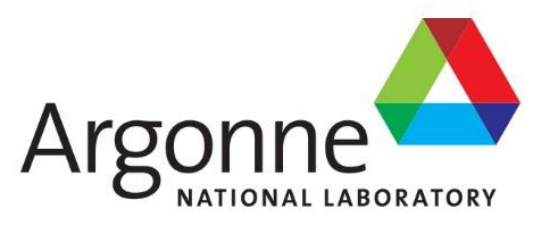

\title{
Impacts of Electrification of Light-Duty Vehicles in the United States, 2010 - 2017
}

Energy Systems Division 


\begin{abstract}
About Argonne National Laboratory
Argonne is a U.S. Department of Energy laboratory managed by UChicago Argonne, LLC under contract DE-AC02-06CH11357. The Laboratory's main facility is outside Chicago, at 9700 South Cass Avenue, Argonne, Illinois 60439. For information about Argonne and its pioneering science and technology programs, see www.anl.gov.
\end{abstract}

\title{
DOCUMENT AVAILABILITY
}

Online Access: U.S. Department of Energy (DOE) reports produced after 1991 and a growing number of pre-1991 documents are available free via DOE's SciTech Connect (http://www.osti.gov/scitech/).

Reports not in digital format may be purchased by the public from the National Technical Information Service (NTIS):

U.S. Department of Commerce

National Technical Information Service

5301 Shawnee Road

Alexandria, VA 22312

www.ntis.gov

Phone: (800) 553-NTIS (6847) or (703) 605-6000

Fax: (703) 605-6900

Email: orders@ntis.gov

Reports not in digital format are available to DOE and DOE contractors from:

U.S. Department of Energy

Office of Scientific and Technical Information

P.O. Box 62

Oak Ridge, TN 37831-0062

\footnotetext{
Disclaimer

This report was prepared as an account of work sponsored by an agency of the United States Government. Neither the United States Government nor any agency thereof, nor UChicago Argonne, LLC, nor any of their employees or officers, makes any warranty, express or implied, or assumes any legal liability or responsibility for the accuracy, completeness, or usefulness of any information, apparatus, product, or process disclosed, or represents that its use would not infringe privately owned rights. Reference herein to any specific commercial product, process, or service by trade name, trademark, manufacturer, or otherwise, does not necessarily constitute or imply its endorsement, recommendation, or favoring by the United States Government or any agency thereof. The views and opinions of document authors expressed herein do not necessarily state or reflect those of the United States Government or any agency thereof, Argonne National Laboratory, or UChicago Argonne, LLC.
} 


\section{Impacts of Electrification of Light-Duty Vehicles in the United States, 2010 - 2017}

by

David Gohlke ${ }^{1,2}$ and Yan Zhou ${ }^{1}$

${ }^{1}$ Argonne National Laboratory, Energy Systems Division

${ }^{2}$ AAAS Science and Technology Policy Fellow; United States Department of Energy, Vehicle Technologies Office

January 2018 


\section{CONTENTS}

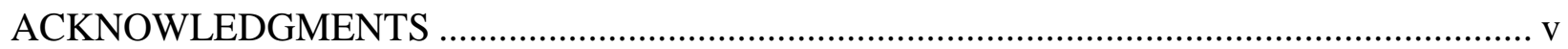

LIST OF ACRONYMS ......................................................................................... vi

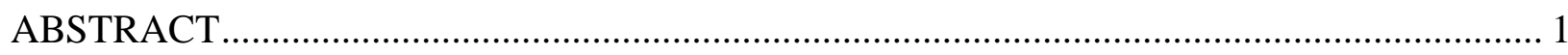

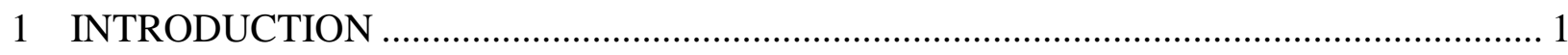

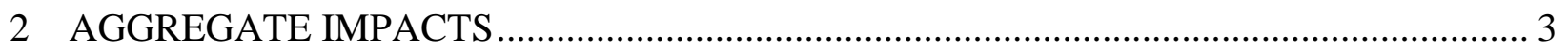

2.1 Electric Miles Traveled ...................................................................................... 4

2.2 Electricity Consumption by PEVs ............................................................... 4

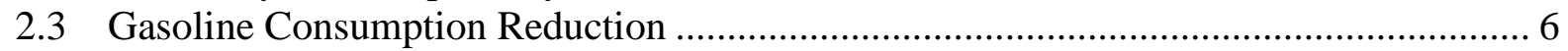

2.4 Carbon Dioxide Emissions ............................................................................... 7

2.5 National-Scale Comparisons ............................................................................. 7

3 VEHICLE CHARACTERISTICS ….................................................................... 9

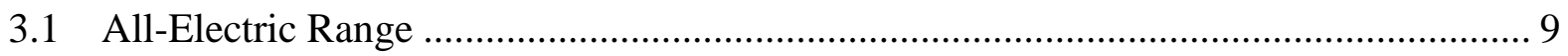

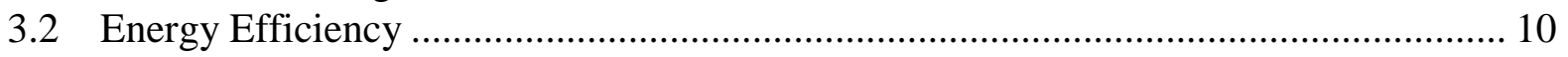

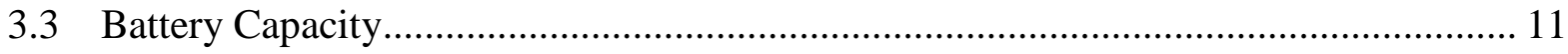

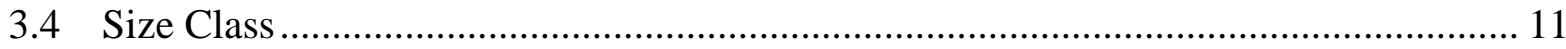

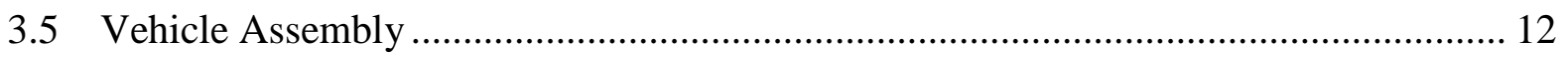

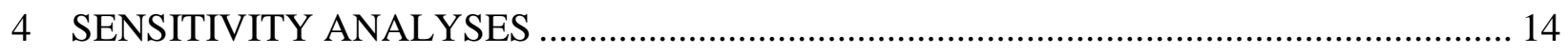

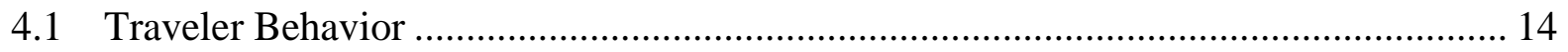

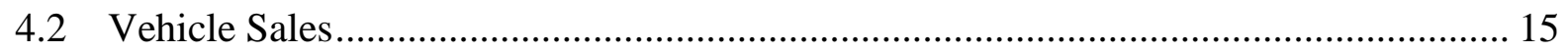

4.3 Comparable ICE Vehicles........................................................................ 16

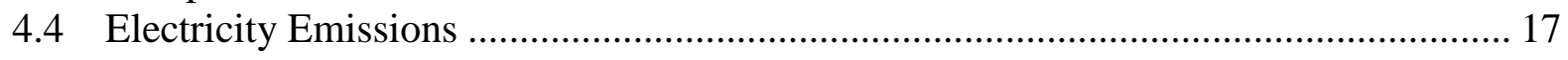

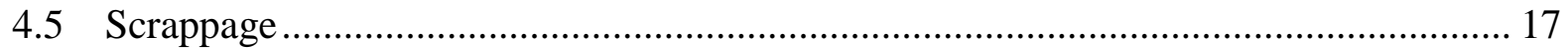

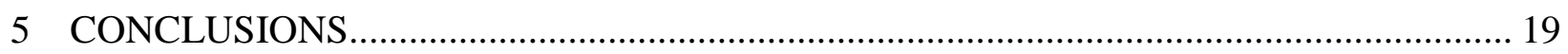

APPENDIX A: UTILITY FACTORS AND TRAVEL BEHAVIOR .................................... 21

APPENDIX B: COMPARISON WITH OTHER REPORTS ........................................... 23

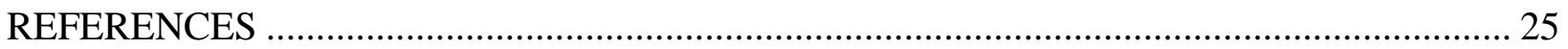




\section{FIGURES}

1 Annual sales of PEVs in the United States by year ............................................................ 3

2 Electric vehicle miles traveled by LDVs by year ………................................................ 5

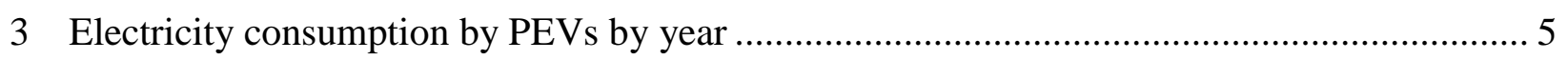

4 Gasoline displacement from ICE vehicles by LDV PEVs by year ........................................ 6

5 Fraction of key national metrics which are due to PEVs in the United States by year ............ 8

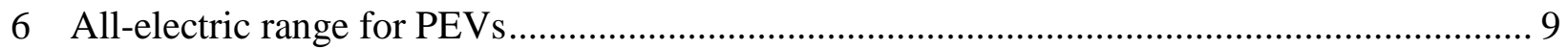

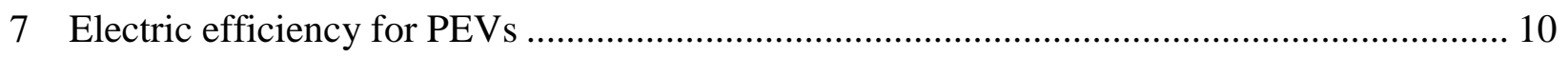

8 Battery capacity added each year for LDV PEVs in the United States ................................... 11

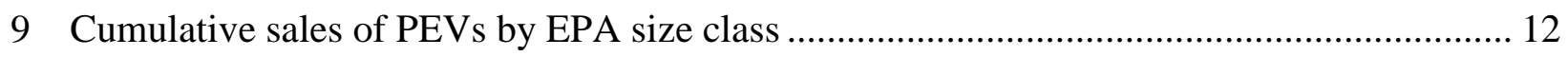

10 Assembly location for PEVs sold in the United States through 2017 .................................. 13

11 Cumulative PEV battery capacity remaining on road and scrapped by month ...................... 18

12 Comparison of PHEV utility factor from SAE and WLTP …………………………........... 21

13 Comparison of effective utility factor for PHEVs and BEVs and on-road data..................... 22

\section{TABLES}

1 Sensitivity of eVMT, Gasoline Reduction, Electricity Consumption, and $\mathrm{CO}_{2}$ Emissions Reduction with Different Driving Behaviors .............................................. 14

2 Sensitivity of eVMT to BEV effective utility factor reduction .............................................. 15

3 Comparison of Total Gasoline Reduction and $\mathrm{CO}_{2}$ Emissions Reduction with Different ICE Vehicles for Comparison ........................................................................ 17

4 Annual Sales of New PEVs, and Total Annual eVMT, Gasoline Reduction, Electricity Consumption, and $\mathrm{CO}_{2}$ Emissions Reduction by On-Road PEVs ......................... 19

5 Comparison of eVMT for PEVs as a Function of Assumed Utility Factor ............................. 22 


\section{ACKNOWLEDGMENTS}

This activity was supported by the Vehicle Technologies Office, Office of Energy Efficiency and Renewable Energy, United States Department of Energy and through an American Association for the Advancement of Science (AAAS) Science \& Technology Policy Fellowship served at the Vehicle Technologies Office.

This report was prepared as an account of work sponsored by an agency of the United States government. Neither the United States government nor any agency thereof, nor any of their employees, makes any warranty, express or implied, or assumes any legal liability or responsibility for the accuracy, completeness, or usefulness of any information, apparatus, product, or process disclosed or represents that its use would not infringe privately owned rights. Reference herein to any specific commercial product, process, or service by trade name, trademark, manufacturer, or otherwise does not necessarily constitute or imply its endorsement, recommendation, or favoring by the United States government or any agency thereof. The views and opinions of authors expressed herein do not necessarily state or reflect those of the United States government or any agency thereof. 


\section{LIST OF ACRONYMS}

ANL

BEV

CARB

DOE

DOT

EIA

EPA

eVMT

FHWA

FUF

GM

ICE

$\mathrm{kWh}$

LDV

MDIUF

mpg

MPGe

MY

NHTSA

PEV

PHEV

REx

SAE

SEPA

SUV

UNECE

VMT

WLTP
Argonne National Laboratory

Battery Electric Vehicle

California Air Resources Board

Department of Energy

Department of Transportation

Energy Information Administration

Environmental Protection Agency

electric vehicle miles traveled

Federal Highway Administration

Fleet Utility Factor

General Motors

internal combustion engine

kilowatt-hour

light-duty vehicle

Multi-Day Individual Utility Factor

miles per gallon

miles per gallon gasoline equivalent

model year

National Highway Traffic Safety Administration

Plug-in Electric Vehicle

Plug-in Hybrid Electric Vehicle

range extender

Society of Automotive Engineers

Smart Electric Power Alliance

sport utility vehicle

United Nations Economic Commission for Europe

vehicle miles traveled

World harmonized Light vehicles Test Procedure 


\title{
IMPACTS OF ELECTRIFICATION OF LIGHT-DUTY VEHICLES IN THE UNITED STATES, 2010 - 2017
}

\begin{abstract}
This report examines the sales of plug-in electric vehicles (PEVs) in the United States from 2010 to 2017, exploring vehicle sales, electricity consumption, petroleum reduction, and battery production, among other factors. Over 750,000 PEVs have been sold, driving nearly 16 billion miles on electricity, thereby reducing gasoline consumption by $0.1 \%$ in 2016 and 600 million gallons cumulatively through 2017, while using over 5 terawatt-hours of electricity. Over 23 gigawatt-hours of battery capacity has been placed in vehicles, and $98 \%$ of this is still on the road, assuming typical scrappage rates.
\end{abstract}

\section{INTRODUCTION}

While traditional gasoline- and diesel-powered internal combustion engines (ICE) are the most common light-duty drivetrain worldwide, alternative-fuel drivetrains are rapidly increasing in market share. In particular, Plug-in Electric Vehicles (PEVs) are among the fastest growing drivetrains in the United States and worldwide. PEVs get at least a portion of their energy from electricity; Battery Electric Vehicles (BEVs) are powered exclusively by electricity, while Plugin Hybrid Electric Vehicles (PHEVs) have a battery as well as a separate gasoline engine for extended driving range.

Understanding the aggregate impact of these electric vehicles is important when exploring electricity use and petroleum consumption. Electric utilities are working to understand the changes in electricity generation, demand, and required infrastructure (EEI, 2017; SEPA, 2017). Refineries need to know the potential impact on demand for their refining mix; gasoline and diesel are the two most common end products in the United States (DOE, 2017).

Compiling publicly available data on vehicle sales and characteristics allows for a comprehensive assessment of the historical impacts of PEVs in the United States. Sales estimates for this analysis generally come from Argonne National Laboratory (ANL, 2018). The allelectric range, vehicle efficiency, and size class of each model come from the FuelEconomy.gov database, managed by the U.S. Department of Energy (DOE) and Environmental Protection Agency (EPA) (DOE and EPA, 2018). Battery capacity and location for final assembly for each vehicle were established through a mix of press releases, news stories, and information on manufacturer websites.

Section 2 of this report highlights national scale impacts of the electric vehicle fleet. Section 3 explores how characteristics on PEVs have evolved over time. Section 4 presents a detailed sensitivity analysis on several assumptions, including vehicle sales, battery size, and 
driving behavior, to test the robustness of the results. Appendix A details assumptions for electric vehicle miles traveled (eVMT, defined as miles driven that are powered by electricity rather than gasoline), comparing to real-world driving data, and Appendix B compares with other published claims and estimates of eVMT. 


\section{AGgREGATE IMPACTS}

The growth in plug-in electric vehicle sales in the United States has been notable. Over 190,000 plug-in electric vehicles were sold in the United States in 2017, a 20\% increase over 2016, and an eleven-fold gain over 2011. Just over half of these were BEVs, as shown in Figure 1. Through 2017, a total of over 750,000 PEV have been sold, slightly over half of which have been PHEV. In 2012, 73\% of PEVs were PHEV, due largely to the popularity of the top two models in that year, the Chevrolet Volt and the Toyota Prius Plug-in. In all other years, the split between BEV and PHEV has been much more even.

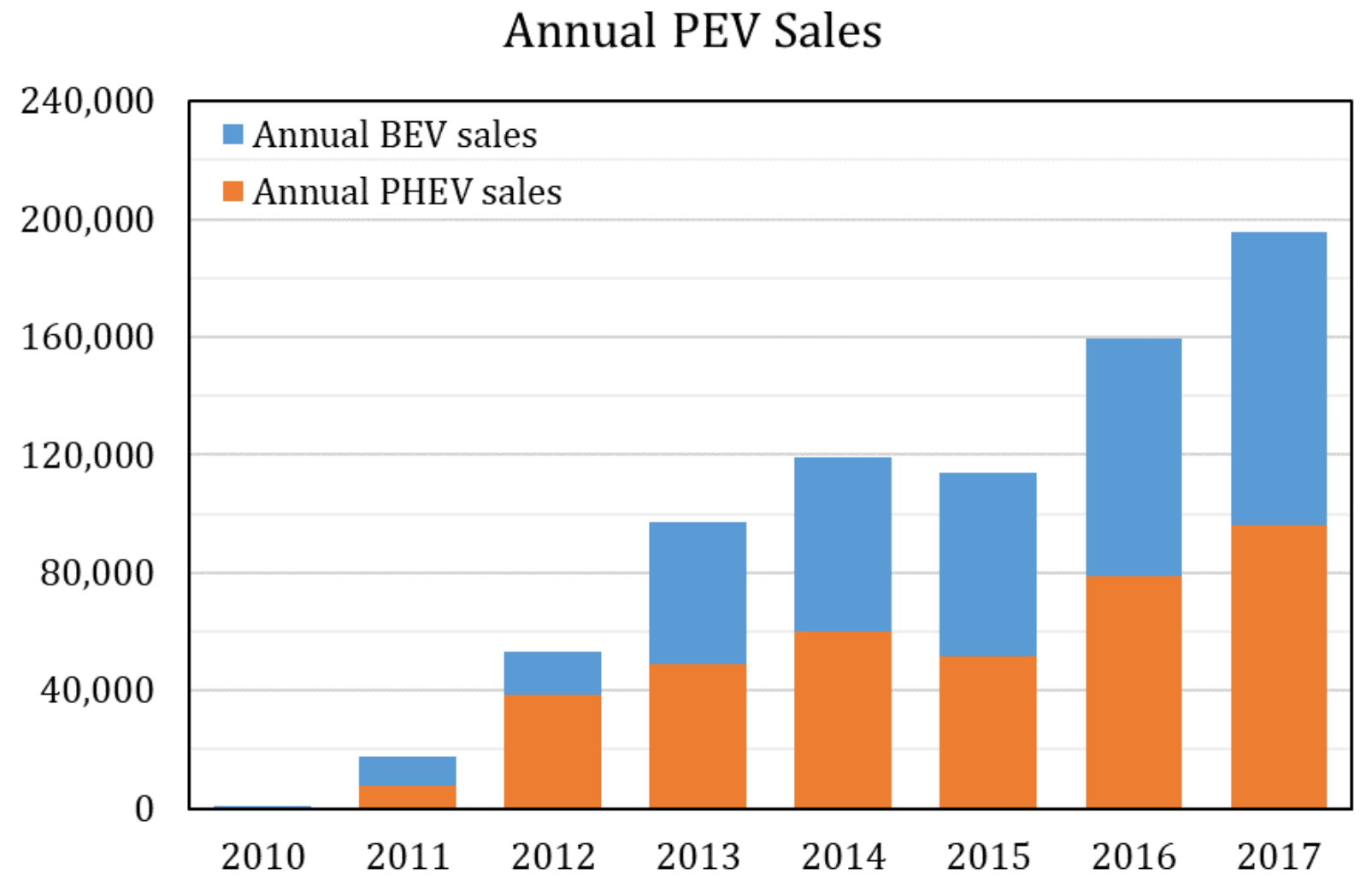

FIGURE 1 Annual sales of PEVs in the United States by year

From 2011 to 2017, annual PEV sales grew from under 18,000 to nearly 200,000, equivalent to a year-over-year growth rate of 49\%. In all but one year (2015), PEV sales in the United States increased. In 2017, PEVs reached $1.1 \%$ of the total national sales market for new light-duty vehicles. As of 2017, nine models of plug-in electric vehicles have sold over 20,000 units in the United States: Chevrolet Volt, Tesla Model S, Nissan Leaf, Toyota Prius, Ford Fusion Energi, Ford C-Max Energi, Tesla Model X, BMW i3, and the Chevrolet Bolt. Of these, the Volt, Model S, and Leaf have all sold over 100,000 units. 


\subsection{ELECTRIC MILES TRAVELED}

The total annual vehicle miles traveled (VMT) powered by electricity for each PEV depends on traveler behavior and the vehicle's all-electric range. As of December 2017, the average age of an on-road electric vehicle was 2.4 years old; according to mileage schedules from the National Highway Traffic Safety Administration (Lu, 2006) and the EPA (EPA, 2016b) and results from the National Household Travel Survey (Santos et al., 2011), the average ICE car is driven approximately 13,000-14,000 miles per year in its first three years. Therefore, as a baseline for this report, an annual driving distance of 13,500 miles per vehicle is used. Because of the flexibility of a secondary fuel source, PHEVs are assumed to drive the same total distance as ICE vehicles. For PHEVs, the utility factor represents the fraction of total mileage run on electricity rather than gasoline. The utility factor for PHEVs in this report comes from the Society of Automotive Engineers (SAE) J2841 standard, for "multi-day individual" vehicles (SAE, 2010). BEVs do not have a utility factor, as $100 \%$ of their driving is all-electric. However, due to concern of running out of charge, limited charging station availability, and the additional time for charging, BEVs have been found to drive less than other similar vehicles (CARB, 2017a; CARB, 2017b; Carlson, 2015; Nicholas et al., 2017; Plötz et al., 2017; Smart and Salisbury, 2015). For example, the eVMT for the 73-mile all-electric Nissan Leaf BEV was found to be comparable to the eVMT of the (shorter-range) 35-mile electric range Chevrolet Volt PHEV (Smart and Salisbury, 2015). In this report the total annual eVMT of a BEV is assumed to be 15\% lower than the eVMT for a hypothetical PHEV of the same all-electric range, giving BEVs an effective utility factor akin to that for PHEVs. See Appendix A for a detailed discussion on the impact of assumed utility factors and travel behavior.

Given the historic vehicle sales, the vehicle electric range, and the effective utility factor, the total mileage driven in all-electric mode across the entire national light duty vehicle (LDV) fleet can be estimated. Figure 2 shows the total eVMT by year in the United States. Through 2017 , nearly 16 billion miles have been driven powered by electricity. In 2017, 5.8 billion miles on the road were driven by light duty electric vehicles; approximately $58 \%$ of this was driven by BEVs.

\subsection{ELECTRICITY CONSUMPTION BY PEVs}

Combining eVMT with knowledge of vehicle electricity efficiency allows us to determine the total electricity consumption by PEVs in the United States, shown in Figure 3. To find the total electricity consumption, the estimated eVMT in each month is multipled by the electricity consumption per mile for each vehicle model. This graphic for electricity consumption is similar to the graphic for eVMT, though not exactly identical, since every vehicle does not have the same efficiency (or energy consumption per mile). For example, vehicles with a longer driving range tend to be more efficient, particularly for PHEVs. Through 2017, a total of 5.4 terawatt-hours of electricity have been consumed by PEVs. In 2017, the total electricity use for LDVs on the road was 1.9 terawatt-hours. In 2017, the average PHEV consumed 2,500 kilowatt-hours $(\mathrm{kWh})$ of electricity, and the average BEV consumed 3,500 kWh of electricity. 


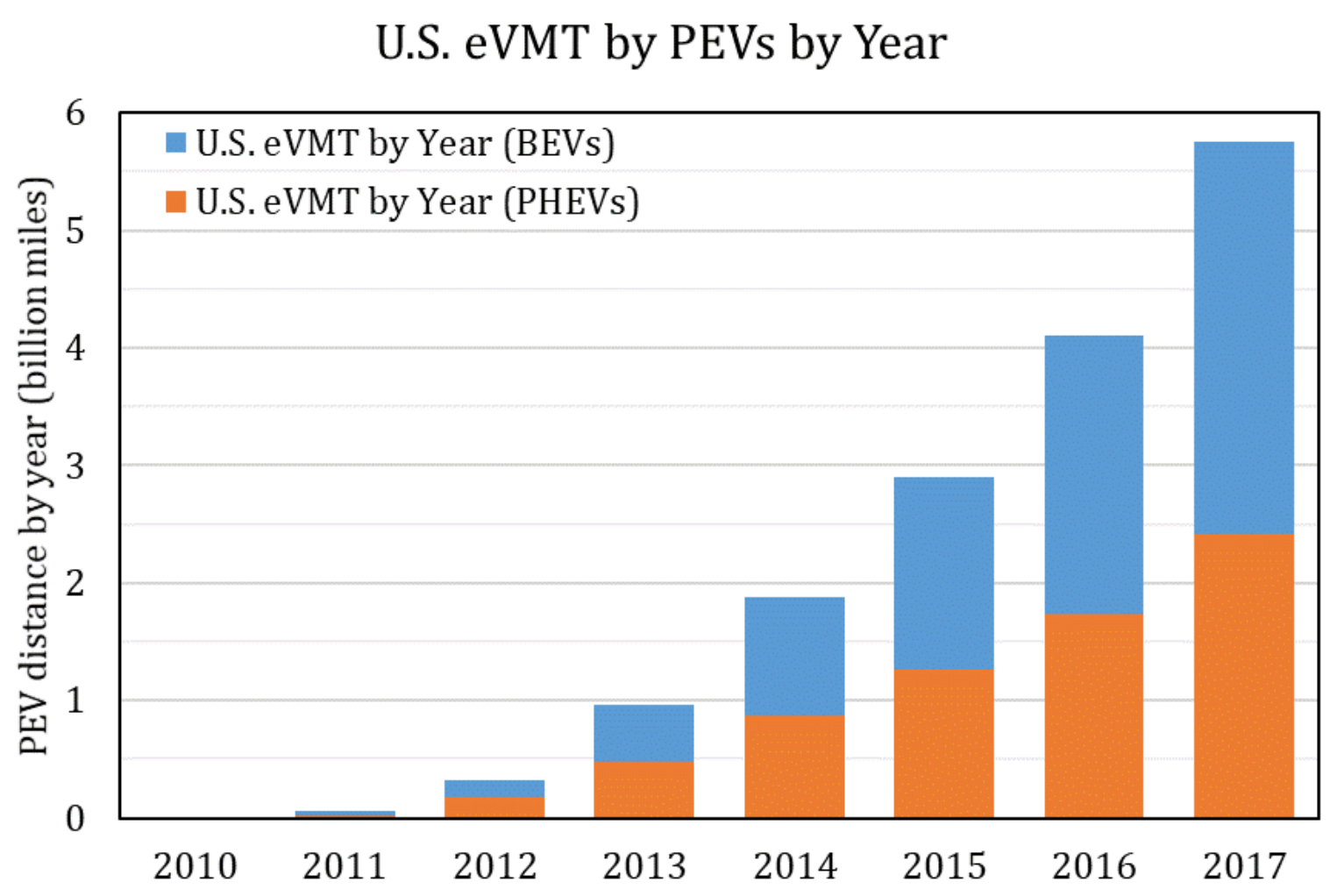

FIGURE 2 Electric vehicle miles traveled by LDVs by year

Electricity Consumption by PEVs by Year

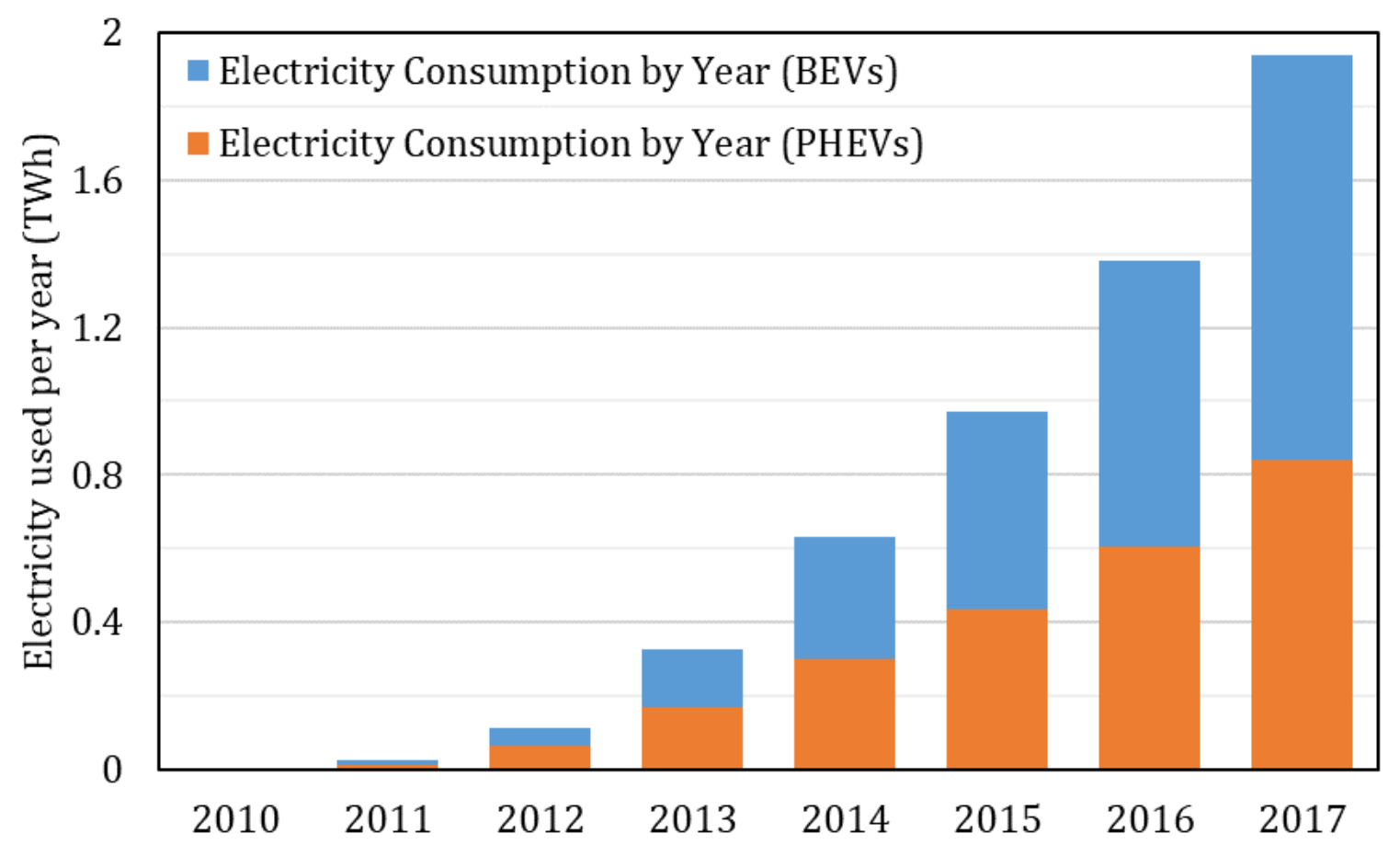

FIGURE 3 Electricity consumption by PEVs by year 


\subsection{GASOLINE CONSUMPTION REDUCTION}

Every electric mile driven is assumed to offset a mile driven on gasoline. For each PEV, a displaced ICE fuel consumption rate is determined to find the total gasoline usage that is offset by electric vehicles. For each model year (MY) and each size class, vehicle fuel efficiencies were gathered from the FuelEconomy.gov database (DOE and EPA, 2018). Given the tendency for early adopters of electric vehicles to be interested in fuel economy and environmental benefits, the comparable gasoline ICE vehicle was assumed to be more fuel efficient than average, specifically, the 75th percentile of models available in that year in that size class. ${ }^{1}$ For example, a compact PEV offsets the fuel consumption of a compact ICE vehicle, rather than comparing with a fleet-wide average. The definition of the ICE reference vehicle is important for estimating total gasoline displacement; Section 4 examines the impact of varying the fuel economy of this reference vehicles.

The total gasoline displacement by year is graphed in Figure 4. In 2017, 210 million gallons of gasoline were offset by PEVs. Sixty percent of this total was offset by BEVs and $40 \%$ by PEVs. In 2017, the average BEV offset nearly 410 gallons of gasoline, and the average PHEV offset 260 gallons. Cumulatively, through 2017, PEVs have offset over 600 million gallons of gasoline, 353 million gallons by BEVs and 248 million gallons by PHEVs.

\section{Gasoline Displacement due to PEVs by Year}

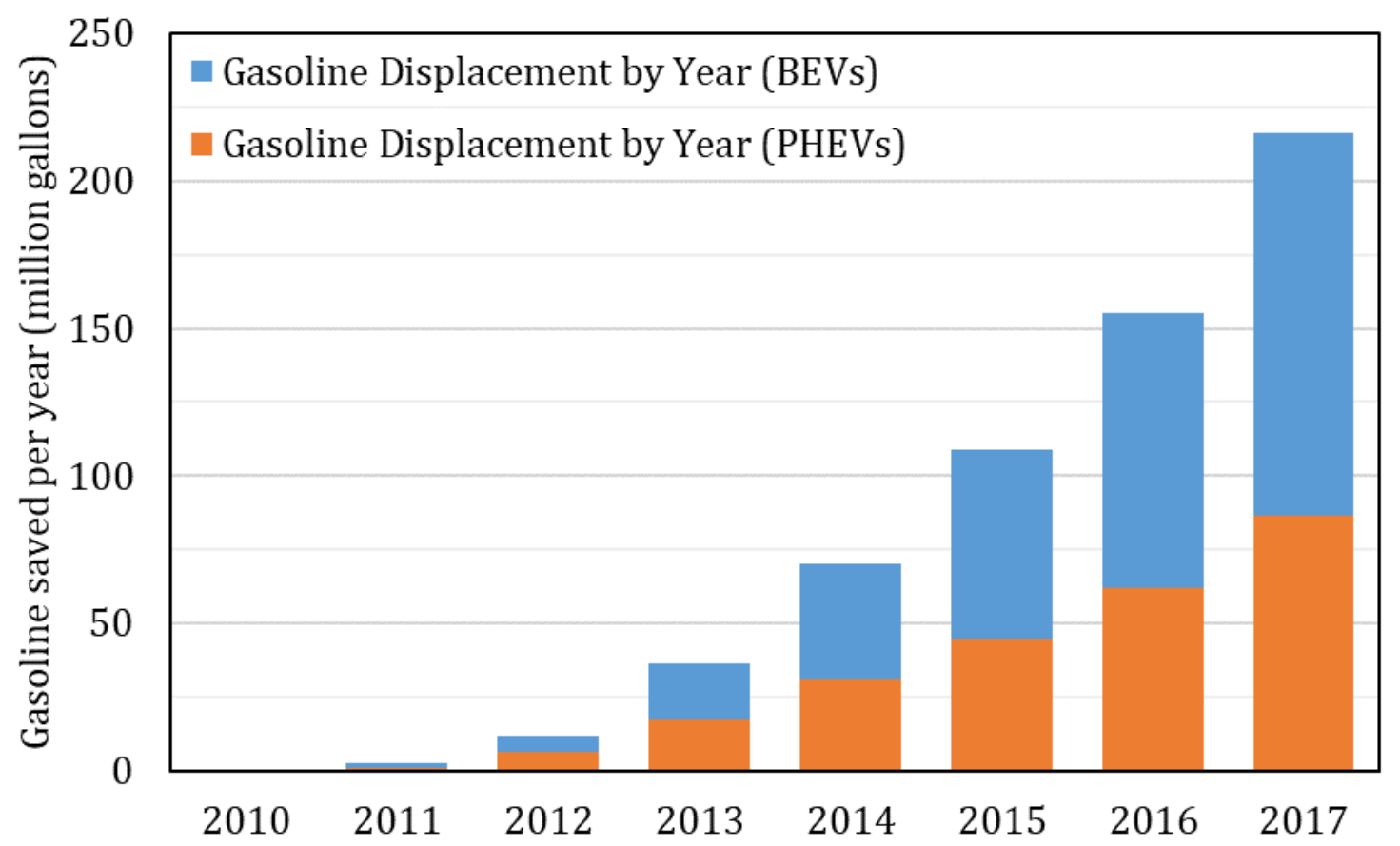

FIGURE 4 Gasoline displacement from ICE vehicles by LDV PEVs by year

\footnotetext{
1 Since the 'Two seater' classification is largely high-performance sports cars, the Smart Fortwo Electric Drive was compared directly with the ICE version of the same vehicle instead of the remainder of the vehicles in that size class.
} 


\subsection{CARBON DIOXIDE EMISSIONS}

Operation of PEVs reduces emissions as well. The EPA states that combustion of each gallon of gasoline emits 8,887 grams of $\mathrm{CO}_{2}$ (EPA and DOT, 2010). ${ }^{2}$ According to the EPA, electricity production in the United States emitted an average of 509 grams of $\mathrm{CO}_{2}$ per kilowatthour in 2014 (EPA, 2017). The amount of tailpipe emissions from an ICE vehicle can be found by multiplying the miles driven by 8,887 grams $\mathrm{CO}_{2} /$ gallon of gasoline and dividing by the fuel economy (in miles per gallon, or mpg), and the emissions to drive an electric vehicle are found by multiplying the miles driven by the electricity consumption (in $\mathrm{kWh}$ per mile) by $509 \mathrm{~g} \mathrm{CO}_{2} /$ $\mathrm{kWh}$. As an example, an ICE vehicle consuming $30 \mathrm{mpg}$ emits $300 \mathrm{~g} \mathrm{CO}_{2} /$ mile, while a BEV consuming $0.33 \mathrm{kWh} /$ mile is responsible for $170 \mathrm{~g} \mathrm{CO}_{2} /$ mile. Assuming the 2014 U.S. national grid average for electricity, and comparing each vehicle with the $75^{\text {th }}$ percentile ICE vehicle for fuel economy in its size class in each year, PEVs have offset a total of 2.6 million metric tons of carbon dioxide during vehicle operation.

\subsection{NATIONAL-SCALE COMPARISONS}

PEVs are a growing share of the vehicle market and are having increasing impacts on the transportation and energy sectors. Figure 5 highlights these changes, comparing the quantities from PEVs for total number of on-road vehicles, miles driven, electricity consumption, and gasoline reduction with corresponding total national values. For most national data, 2016 is the latest year with full data availability as of the writing of this report (January 2018). In 2016, PEVs comprised $0.23 \%$ of the nearly 250 million light-duty vehicle registrations (FHWA, 2017). That year, the Federal Highway Administration found nearly 3 trillion miles driven by light-duty vehicles in the United States (FHWA, 2017), for comparison, over 4 billion of these miles, or $0.14 \%$, were powered by electricity. In 2016, the total electricity use for LDVs on the road was 1.4 terawatt-hours. This compares with a total of 3,902 terawatt-hours (EIA, 2017), or 0.035\% of the total national electricity generation. In 2016, 155 million gallons of gasoline were offset by PEVs, equivalent to $0.11 \%$ of the 138 billion gallons of gasoline used in the United States that year (EIA, 2017).

2 This calculation is for tailpipe emissions only; that is, it excludes upstream effects for refining and transportation of the fuel, as well as emissions from the production of the vehicles. For electric vehicles, the calculation is for the generation of the electricity for vehicle operation, again excluding vehicle manufacturing. The majority of emissions come from the operation, rather than the manufacturing, of both ICE vehicles and PEVs. A recent study found that tailpipe emissions from a midsize gasoline ICE vehicle were $68 \%$ of the total lifetime emissions, while electricity consumption for operation was responsible for $77 \%$ of the emissions from a midsize BEV (Elgowainy et al., 2016). 


\section{PEVs relative to the whole}

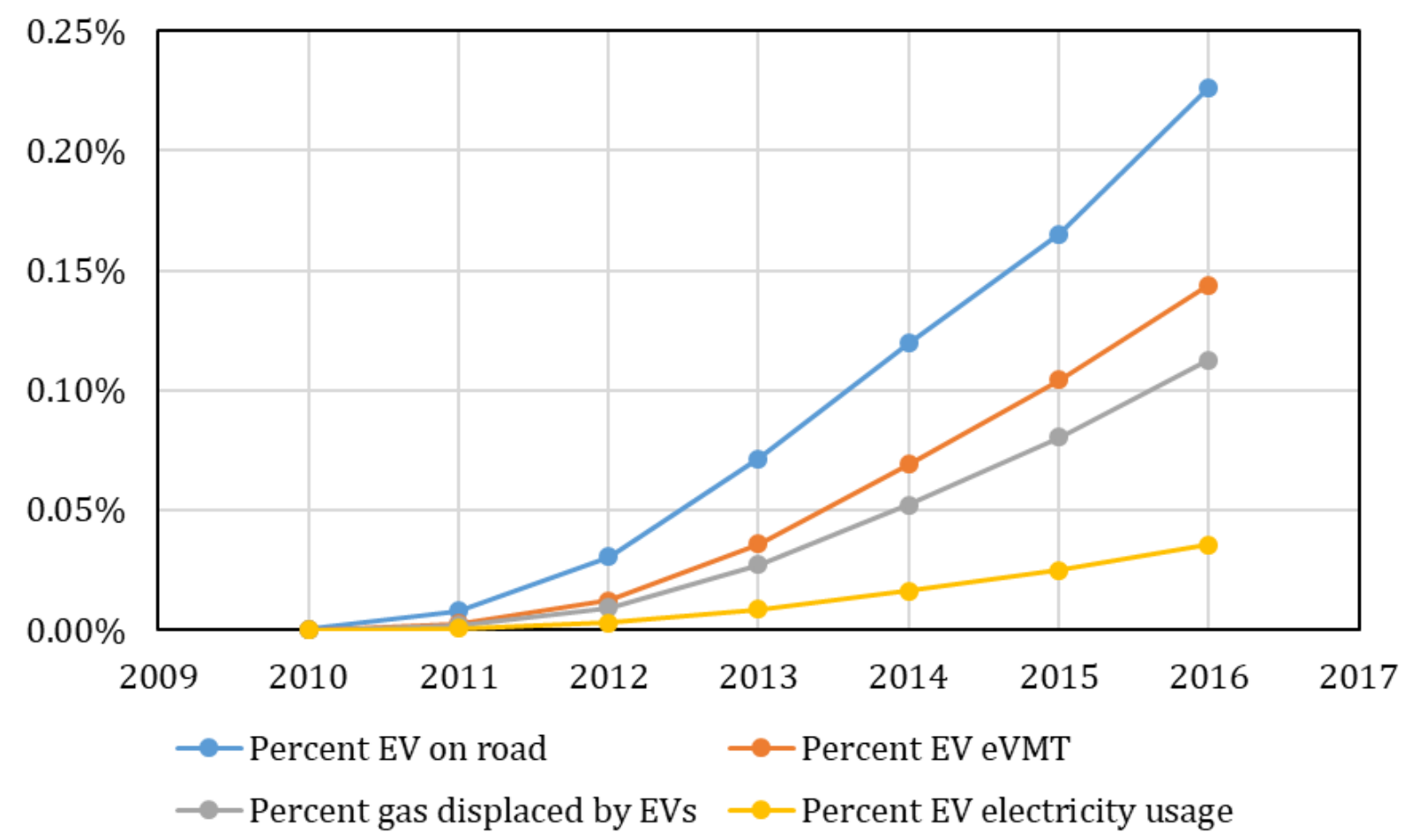

FIGURE 5 Fraction of key national metrics which are due to PEVs in the United States by year 


\section{VEHICLE CHARACTERISTICS}

In addition to the total national-scale impacts of PEVs relative to the whole, specific trends within the PEV market can be examined, including all-electric range, energy efficiency, battery size, vehicle size class, and manufacturing location.

\subsection{ALL-ELECTRIC RANGE}

The average range of PEVs has grown since 2010. This is largely due to the introduction of longer-range BEVs. Figure 6 shows the average sales-weighted all-electric range for new vehicles (left side) and for all on-road vehicles (right side). PHEVs have consistently averaged between 20 and 35 miles of all-electric range while the average range of BEVs has grown from approximately 70 miles to over 160 miles. The sharp growth in all-electric range for BEVs in early 2013 is due to the introduction of the Tesla Model S, with a range of up to 265 miles.
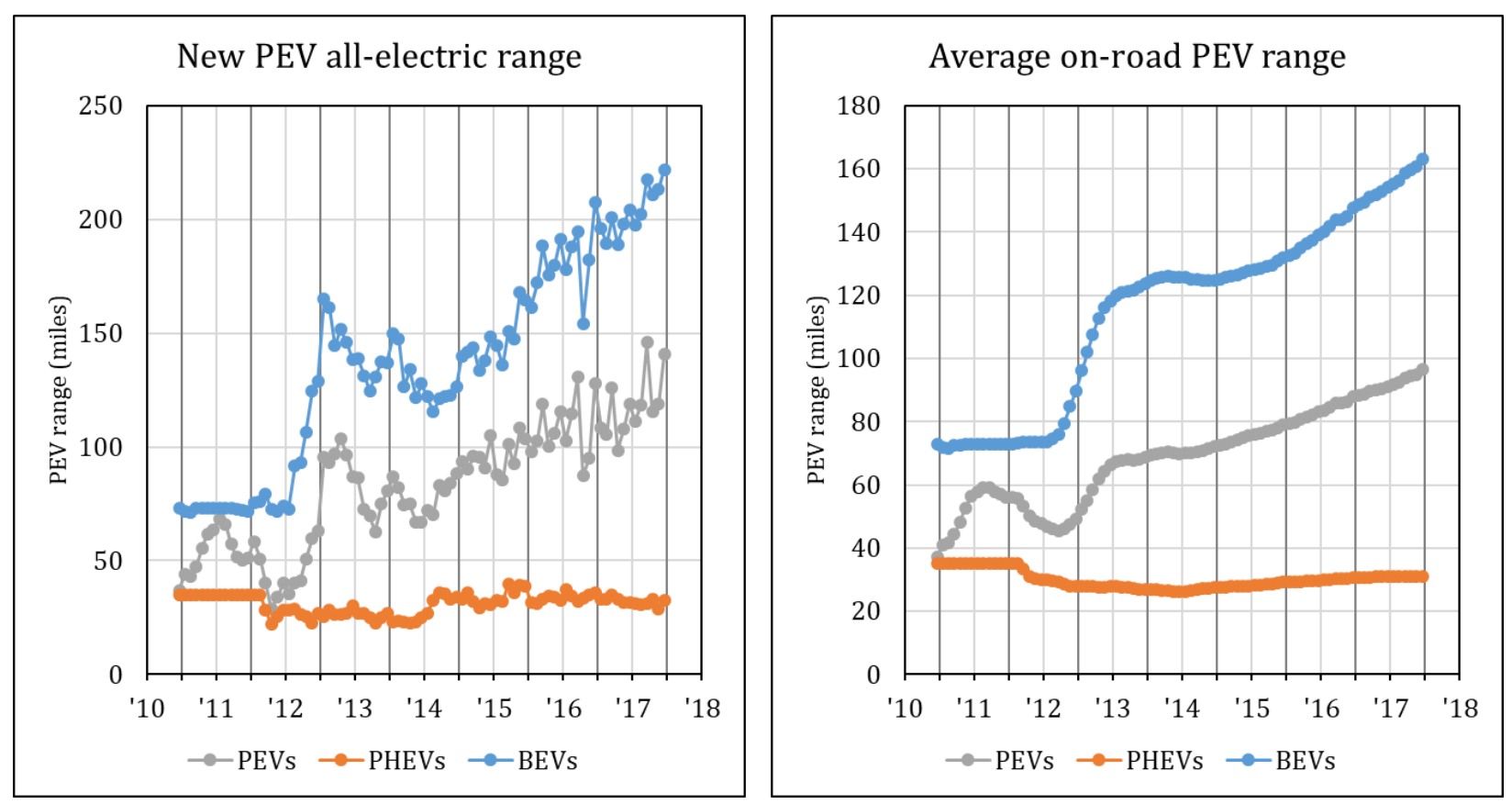

FIGURE 6 All-electric range for PEVs. Left side: new vehicles sold in each month. Right side: average on-road vehicles. 


\subsection{ENERGY EFFICIENCY}

Figure 7 shows the average (distance-weighted) energy efficiency of vehicles running on electricity for new vehicles (left) and the entire on-road fleet of PEVs (right). ${ }^{3}$ Since 2010, vehicles have become more efficient on average. The average electricity consumption of the entire PEV fleet has dropped from nearly $36 \mathrm{kWh}$ per 100 miles to under $34 \mathrm{kWh}$ per 100 miles. In terms of miles per gallon of gasoline equivalent (MPGe), where 33.7 kilowatt-hours of electricity is equivalent to one gallon of gasoline (EPA, 2011), the average PEV fuel economy has increased from 94 MPGe to 100 MPGe.
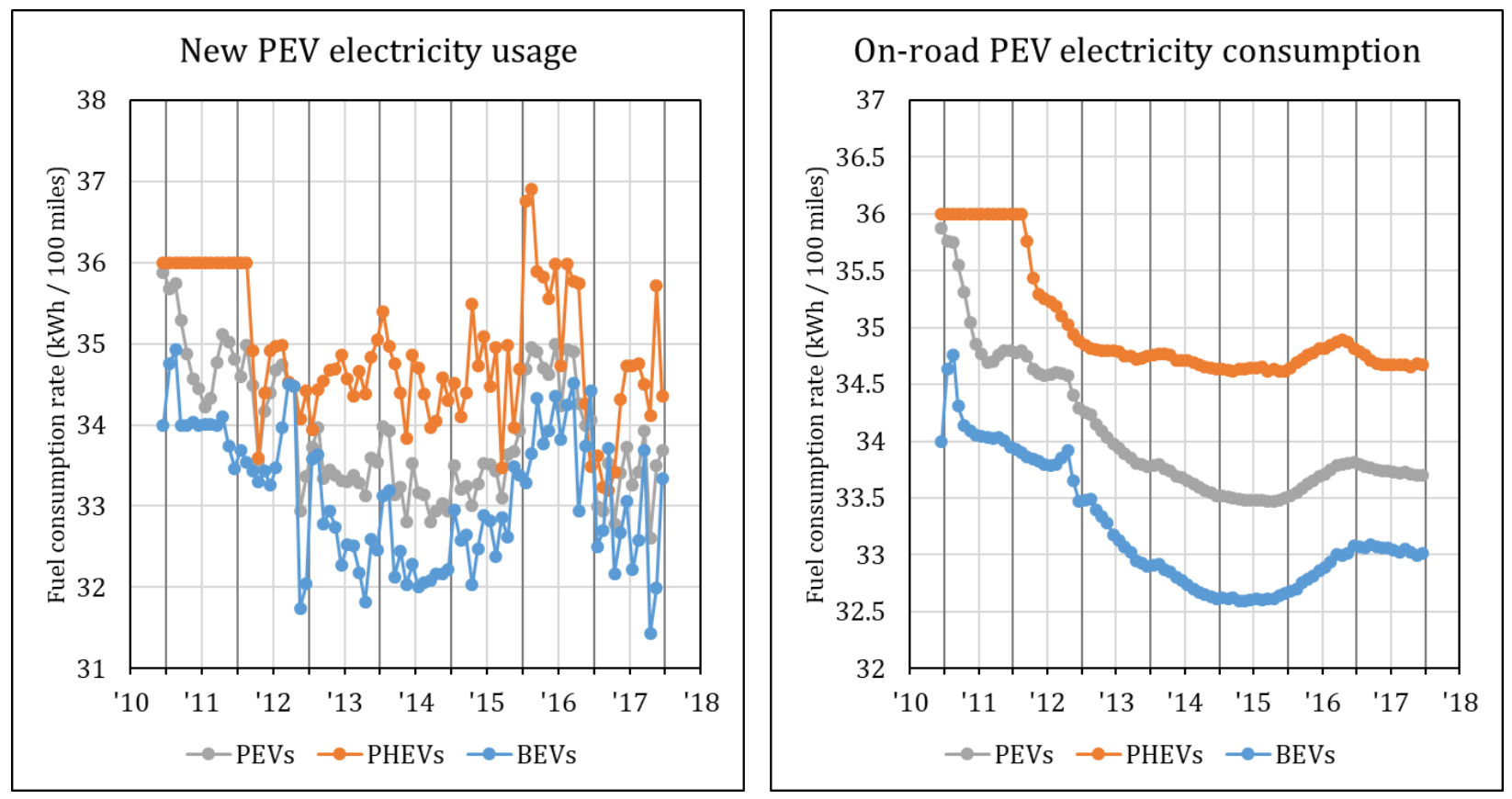

FIGURE 7 Electric efficiency for PEVs. Left side: new vehicles sold in each month. Right side: average on-road vehicles.

BEVs sold in the United States have generally been more efficient than PHEVs. There are $4 \mathrm{BEVs}$ in this database with fuel efficiency worse than $40 \mathrm{kWh} / 100$ miles, while 22 models of PHEVs consume more than $40 \mathrm{kWh} / 100$ miles. The most efficient vehicles in the FuelEconomy.gov database are the Hyundai Ioniq BEV and Toyota Prius Prime PHEVs, each consuming $25 \mathrm{kWh} / 100$ miles when operating on electricity (DOE and EPA, 2018). Longerrange PHEVs tend to have better fuel economy than shorter-range PHEVs, while there is little correlation between all-electric range and battery size for BEVs. Variability in the sales mix

3 A distance-weighted average (rather than a sales-weighted average) gives a proper comparison of electricity consumption of the entire PEV fleet. For BEVs, the sales-weighted and distance-weighted fuel economies have been very similar each month. Since shorter-range PHEVs (around 10-15 mile range) have worse fuel efficiency than longer-range PHEVs in the FuelEconomy.gov database, and do not drive as many miles as those with longer ranges, the distance-weighted average is more efficient than the sales-weighted average for PHEVs. 
leads to relatively large changes in average electricity consumption month-to-month for newly purchased PEVs, while the average of the entire PEV fleet has had smaller monthly variability.

\subsection{BATTERY CAPACITY}

The aggregate battery capacity in PEVs sold in the United States is over 23 gigawatthours through 2017. Figure 8 shows the new batteries added to the road each year from 2010 through 2017; new battery capacity reached 7 gigawatt-hours in 2017. This amount of battery capacity is similar to previously published work (DOE, 2016b; Chung et al., 2015; Chung et al., 2016). More than half of the battery capacity that has been sold has been installed in Tesla vehicles, in particular the Model S and Model X.

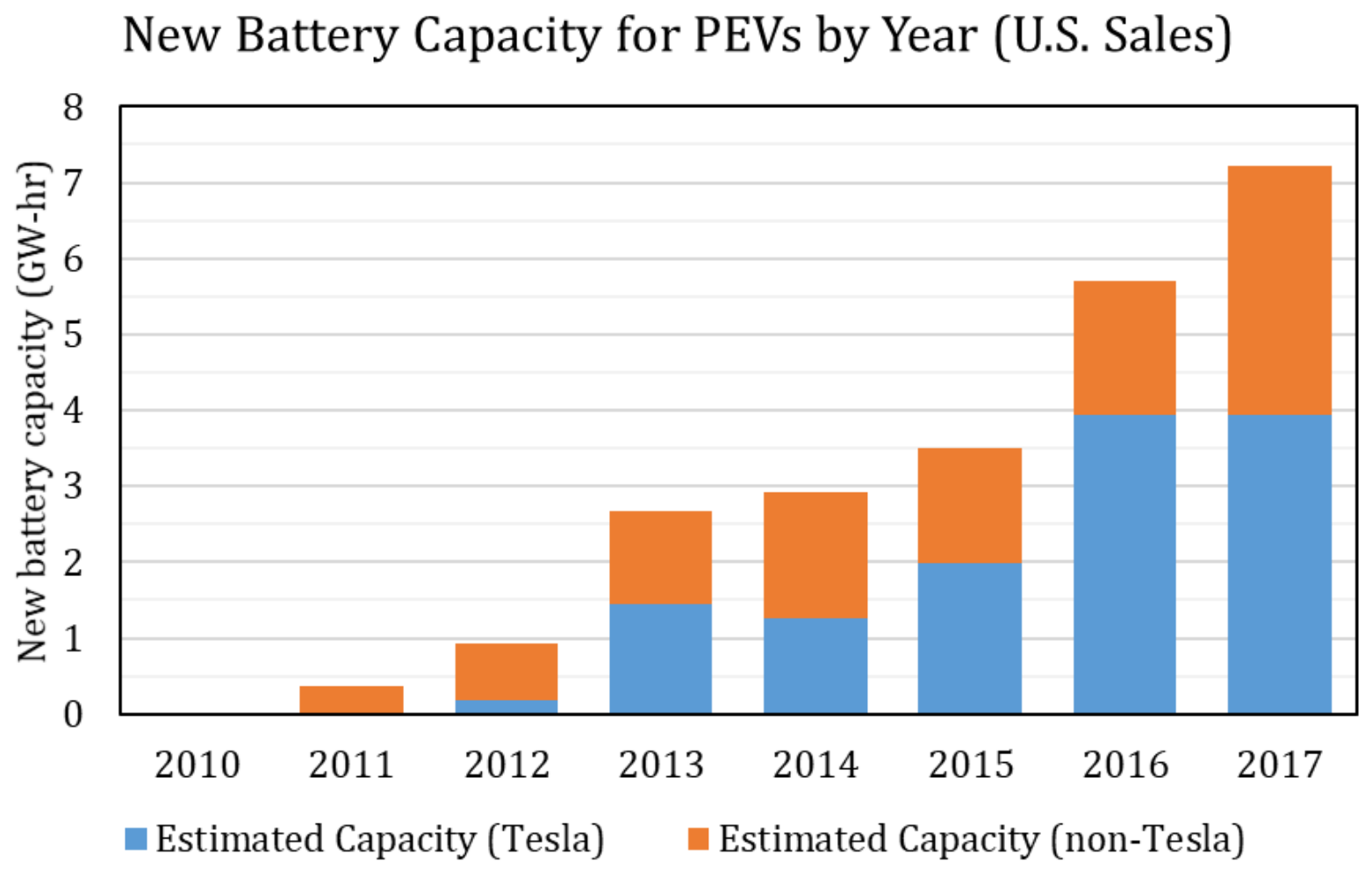

FIGURE 8 Battery capacity added each year for LDV PEVs in the United States

\subsection{SIZE CLASS}

Figure 9 shows PEVs sorted by size class. The most common vehicle each year for PEV sales has been a midsize car. This is followed by compact cars, which are more prominent for PHEVs, such as the Chevrolet Volt, and by large cars, such as the Tesla Model S BEVs. Sales for sport utility vehicle (SUV) PEVs are growing, with standard four-wheel drive SUV being the third best-selling size class of 2017. 


\title{
On-road PEVs by size class
}

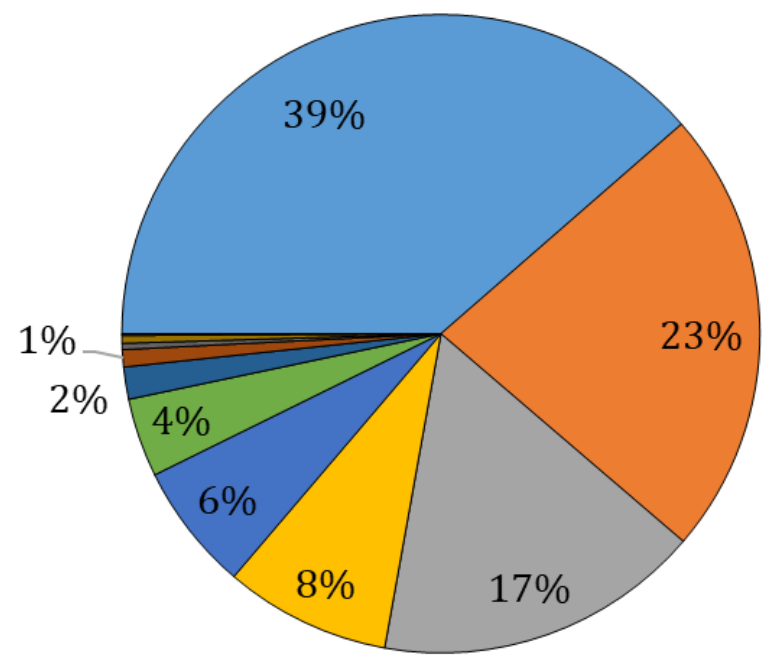

\author{
$\square$ Midsize Cars \\ $\square$ Compact Cars \\ $\square$ Large Cars \\ $\square$ Standard Sport Utility Vehicle 4WD \\ $\square$ Subcompact Cars \\ $\square$ Small Station Wagons \\ $\square$ Minicompact Cars \\ $\square$ Two Seaters \\ $\square$ Small Sport Utility Vehicle 2WD \\ $\square$ Minivan - 2WD \\ - Small Sport Utility Vehicle 4WD
}

FIGURE 9 Cumulative sales of PEVs by EPA size class

The EPA splits LDVs into five different vehicle types: cars, car SUVs, truck SUVs, minivans/vans and pickup trucks (EPA 2016a). Vehicles defined as cars by the EPA make up 91\% of total PEV sales; 6\% of PEV sales have been car SUVs, and 3\% have been truck SUVs. In 2017, car SUVs comprised over $21 \%$ of BEV sales, and truck SUVs were over $10 \%$ of PHEV sales.

\subsection{VEHICLE ASSEMBLY}

Most electric vehicles sold in the United States were assembled in the United States, as shown in Figure 10. Over four-fifths of BEVs and nearly two-thirds of PHEVs have been assembled in the United States. Most of the remaining PEVs sold in the United States were assembled in Germany or Japan. 


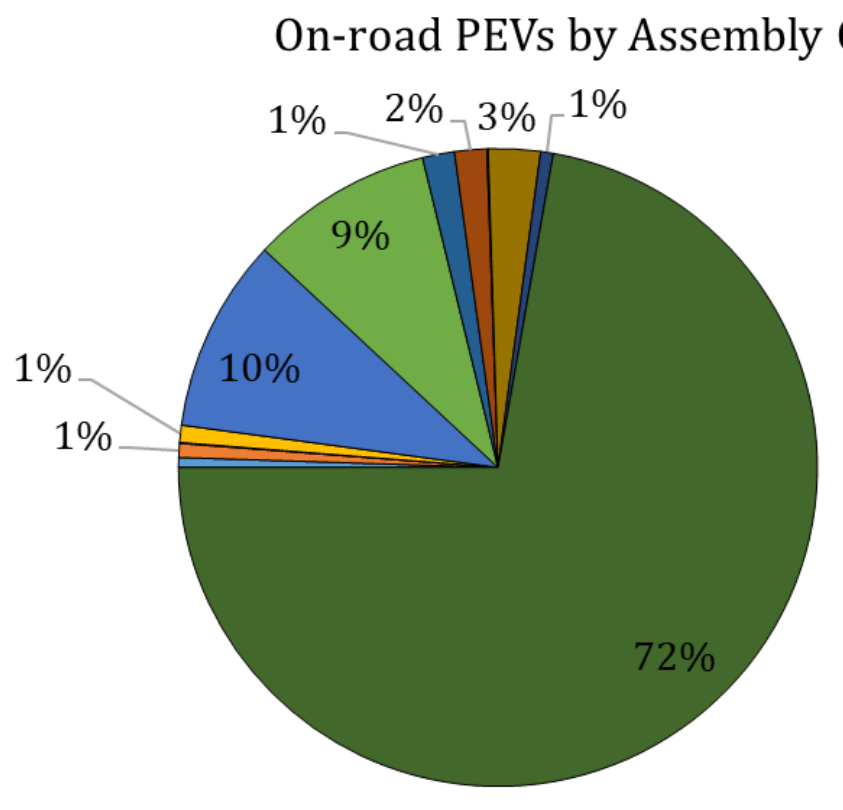

$\square$ Austria

$\square$ Canada

$\square$ China

$\square$ France

$\square$ Germany

$\square$ Japan

$\square$ Malaysia

$\square$ Mexico

$\square$ Netherlands

$\square$ South Korea

$\square$ Sweden

$\square$ United States

FIGURE 10 Assembly location for PEVs sold in the United States through 2017 


\section{SENSITIVITY ANALYSES}

To examine the robustness of the results, certain parameters were varied, including vehicle sales data, eVMT estimates, and different ICE vehicles for comparison. Scrappage and end-of-life are also potentially a key concern.

\subsection{TRAVELER BEHAVIOR}

The baseline VMT in this study was fixed at 13,500 miles/year. As noted above in Section 2, this corresponds to the average distance driven by a comparable ICE vehicle (Lu, 2006). Tuning this parameter affects all vehicles equally and acts as a simple scaling factor for eVMT, electricity consumption, gasoline displacement, and $\mathrm{CO}_{2}$ emissions. The fraction of PHEV VMT driven on electricity is determined by a utility factor, and BEVs have an effective utility factor in this report, which can be thought of as representing driver reluctance to fully discharge the battery or use BEVs for long-distance trips. These behavioral factors are strongly dependent on the vehicle make and model, and average values are used in this report. Appendix A compares different utility factors as well as their relation to real-world data. Appendix B compares these estimates to press releases and other calculations of eVMT.

Table 1 shows the range of impacts attributable to PEVs, while varying eVMT parameters. The baseline assumptions yield 16.0 billion eVMT across all PEVs through December 2017. By using a 12,000 mile/year baseline, the SAE Fleet Utility Factor (FUF) as the PHEV eVMT fraction, and a 30\% reduction in BEV miles, eVMT is 12.0 billion miles, 25\% lower than the baseline case. Conversely, a 15,000 mile/year baseline assuming the SAE MultiDay Individual Utility Factor (MDIUF) with no reduction in BEV miles results in 19.5 billion eVMT, a 22\% increase over the baseline case.

TABLE 1 Sensitivity of eVMT, Gasoline Reduction, Electricity Consumption, and $\mathrm{CO}_{2}$ Emissions Reduction with Different Driving Behaviors

\begin{tabular}{lcccc}
\hline & $\begin{array}{c}\text { Gasoline } \\
\text { reduction } \\
\text { (billion miles) }\end{array}$ & $\begin{array}{c}\text { Electricity } \\
\text { consumption } \\
\text { (million gallons) }\end{array}$ & $\begin{array}{c}\mathrm{CO}_{2} \text { emissions } \\
\text { reduction } \\
\text { (million metric } \\
\text { tons) }\end{array}$ \\
\hline $\begin{array}{l}\text { MDIUF, 13,500 miles, 15\% BEV } \\
\text { reduction [baseline] }\end{array}$ & 16.0 & 601 & 5.38 & 2.60 \\
$\begin{array}{l}\text { FUF, 12,000 miles, 30\% BEV } \\
\text { reduction }\end{array}$ & 12.0 & 450 & 4.05 & 1.94 \\
$\begin{array}{l}\text { MDIUF, 12,000 miles, 30\% BEV } \\
\text { reduction }\end{array}$ & 12.8 & 479 & 4.32 & 2.06 \\
$\begin{array}{l}\text { MDIUF, 15,000 miles, 0\% BEV } \\
\text { reduction }\end{array}$ & 19.5 & 737 & 6.56 & 3.21 \\
\hline
\end{tabular}


When adjusting only the BEV mileage reduction, the relative benefits of PHEV and BEV change. As described above, the baseline in this report assumes that a BEV has a $15 \%$ reduction in eVMT relative to a hypothetical PHEV with the same all-electric range. Table 2 shows how varying this factor affects total eVMT and the share of eVMT due to BEV and PHEV.

Using a constant reduction of $15 \%$ is likely an oversimplification of traveler behavior. When drivers have confidence in charging availability and convenience, the BEV can be more efficiently utilized. In particular, longer-range BEVs appear to have a smaller reduction than shorter-range BEVs (see Appendix A). Table 2 includes a case where the effective utility factor for the BEV is equal to the square of the PHEV utility factor. In this case, short-range BEV ( $<70$ mile all-electric range) are penalized with fewer total VMT, while medium- and long-range $\mathrm{BEV}$ (>100 mile all-electric range) have a reduced penalty. This effective utility factor is graphed in Figure 13 in Appendix A.

\section{TABLE 2 Sensitivity of eVMT to BEV effective utility factor reduction}

\begin{tabular}{lccc}
\hline \multicolumn{1}{c}{$\begin{array}{c}\text { BEV mileage reduction } \\
\text { (relative to utility factor) }\end{array}$} & $\begin{array}{c}\text { PEV eVMT } \\
\text { (billion miles) }\end{array}$ & $\begin{array}{c}\text { BEV eVMT } \\
\text { (billion miles) }\end{array}$ & $\begin{array}{c}\text { Fraction of eVMT } \\
\text { from BEVs }\end{array}$ \\
\hline 15\% BEV reduction [baseline] & 16.0 & 9.0 & $56.4 \%$ \\
0\% BEV reduction & 17.6 & 10.6 & $60.2 \%$ \\
30\% BEV reduction & 14.4 & 7.4 & $51.7 \%$ \\
Squared utility factor & 16.5 & 9.5 & $57.7 \%$ \\
\hline
\end{tabular}

\subsection{VEHICLE SALES}

Default sales estimates come from Argonne National Laboratory (ANL, 2018) and HybridCars (Cobb, 2018). For comparison, estimates for sales from InsideEVs were used as well (Inside EVs, 2018). Several manufacturers, most notably Tesla, do not report U.S. sales monthly for each model, so there are differences between these sales estimates. The InsideEVs data also includes 4,391 vehicles sold before 2011. InsideEVs reports approximately $1.7 \%$ more cumulative total sales through December 2017, resulting in 3\% more electricity usage and gasoline displacement.

Tesla reports sales quarterly and globally and aggregates across all trim levels for each model. This results in uncertainty for sales estimates and about which vehicles were sold. For example, for MY2016, 13 different trim levels were available for the Model S, with battery sizes ranges from $60 \mathrm{kWh}$ to $100 \mathrm{kWh}$, efficiencies ranging from $0.32 \mathrm{kWh} / \mathrm{mile}$ to $0.38 \mathrm{kWh} / \mathrm{mile}$, and all-electric ranges from 210 miles to 315 miles. However, because the effective utility factor for the Model S and Model X is high for every model, the impact of the exact variation in Tesla vehicle attributes is small for the macroeconomic aggregated indicators. For example, for MY2016 Tesla Model S there is a 51\% difference between the shortest and longest driving ranges. However, using the FUF and MDIUF utility factors for PHEVs, their difference in effective utility factor is less than $3 \%$. Uncertainty in the vehicle mix does have a major impact 
on total battery production, which ranges between $20.4 \mathrm{GWh}$ and $26.3 \mathrm{GWh}$ through December 2017 depending on if all Model S and Model X have the smallest or largest batteries available, respectively.

BMW does not separate out the $\mathrm{i} 3 \mathrm{BEV}$ model from the range extender (REx) model in its monthly sales reports, however it is believed that $77 \%$ of i3s sold in the United States through February 2017 were REx vehicles (Cole, 2017). Varying this fraction has little impact on the aggregate benefits (the BEVs are assumed to drive a little less, but otherwise the vehicles are similar), but does change the relative attribution between BEV and PHEV. If all i3 were REx, $55 \%$ of all eVMT would be by BEVs, whereas if none were REx, $59 \%$ of all eVMT would be by BEVs.

Nissan offered two different versions of the MY2017 Leaf, one with a $24 \mathrm{kWh}$ battery offering 84 miles of all-electric range, and one with a $30 \mathrm{kWh}$ battery with 107 miles of allelectric range. This analysis uses the base model of $24 \mathrm{kWh}$ as the default assumption. Assuming all of these vehicles had $30 \mathrm{kWh}$ batteries instead results in a total increase of less than $0.1 \%$ for total eVMT or gasoline displacement through December 2017.

\subsection{COMPARABLE ICE VEHICLES}

Rather than using the $75^{\text {th }}$ percentile vehicle in each size class, different comparison ICE vehicles can be used for PEVs. Table 3 shows the impact of changing the comparable vehicle. The total eVMT and electricity consumption do not vary, but the gallons of gasoline offset through 2017 ranges from 400 to 700 million gallons and cumulative $\mathrm{CO}_{2}$ reductions range from 0.8 to 3.5 million metric tons. The lower bound comes from all PEVs replacing an ICE vehicle consuming 40 miles per gallon, while the upper bound scenario has all PEVs replace the average ICE vehicle in its size class.

In Table 3, the first row represents PEVs replacing a gasoline-fueled ICE vehicle equivalent in fuel economy to the $75^{\text {th }}$ percentile vehicle in that size class for that year. The second row takes the harmonic mean of fuel economy for all vehicles in the size class for each year and uses that as the displaced vehicle. The third row represents PEVs replacing an ICE vehicle equivalent to the average of vehicles with better fuel economy than the $75^{\text {th }}$ percentile in that size class. The bottom three rows treat all PEVs the same, regardless of size class, as if they are replacing an average ICE vehicle with fuel economy equivalent to the average vehicle sale in that year, $30 \mathrm{mpg}$, or $40 \mathrm{mpg}$, respectively. 
TABLE 3 Comparison of Total Gasoline Reduction and $\mathrm{CO}_{2}$ Emissions Reduction with Different ICE Vehicles for Comparison

\begin{tabular}{lcc}
\hline \multicolumn{1}{c}{ Replaced ICE vehicle } & $\begin{array}{c}\text { Gasoline reduction } \\
\text { (million gallons) }\end{array}$ & $\begin{array}{c}\mathrm{CO}_{2} \text { emissions reduction } \\
\text { (million metric tons) }\end{array}$ \\
\hline $75^{\text {th }}$ percentile by size class [baseline] & 601 & 2.60 \\
Average by size class & $699(+16.2 \%)$ & $3.47(+33.3 \%)$ \\
Average of top quartile in size class & $536(-10.9 \%)$ & $2.02(-22.3 \%)$ \\
Fleet average (EPA, 2016a) & $653(+8.6 \%)$ & $3.06(+17.6 \%)$ \\
30 miles per gallon & $532(-11.5 \%)$ & $1.99(-23.5 \%)$ \\
40 miles per gallon & $399(-33.6 \%)$ & $0.81(-69.0 \%)$ \\
\hline
\end{tabular}

\subsection{ELECTRICITY EMISSIONS}

As noted in Section 2, PEVs have offset 2.6 million metric tons of carbon dioxide during vehicle operation, assuming the 2014 U.S. national grid average. This number is likely an underestimate, as many electric vehicles have been sold in California (DOE, 2016a), which is on the WECC grid and emits less carbon dioxide per kilowatt-hour than the national average (EPA, 2017). A grid with electricity generation weighted across all 9 grid regions by the sales-weighted average of BEVs has $8 \%$ lower $\mathrm{CO}_{2}$ emissions per kilowatt-hour generated compared to the national grid average (Kelly et al., 2017). This corresponds to an $8 \%$ greater reduction in total $\mathrm{CO}_{2}$ emissions, relative to comparable ICE vehicles.

\subsection{SCRAPPAGE}

Scrappage effects are currently small. Using National Highway Traffic Safety Administration's (NHTSA) 2006 report as the basis of scrappage rates, which uses historic data from ICE vehicles (Lu, 2006), less than 3\% of PEVs sold have been taken off the road, as of December 2017. ${ }^{4}$ This fraction is small because of the average age of PEVs. The average age of PEVs is only 29 months, due to their recent introduction into the market and the rapid growth in sales. If PEV sales remain steady at 2017 levels (16,000 sales per month), scrappage will not reach $10 \%$ until 2024, and the overall fraction will be lower still if PEV sales increase (due to a younger average PEV fleet).

A potentially larger impact comes from reduction of vehicle use as the vehicle ages. NHTSA has a vehicle mileage schedule for estimated travel by age of vehicle, based on historical ICE data (Lu, 2006). Translating this vehicle mileage schedule (for cars) to the PEV sales since 2010 yields a 4.5\% reduction in monthly VMT in December 2017 and a total reduction of $3 \%$ from 2010 through 2017. It is unknown if this methodology translates to eVMT driven by PEVs. For BEVs, a reduction in VMT is identical to a reduction in eVMT though

\footnotetext{
4 For the first several years of a vehicle's life, the scrappage rate from NHTSA is approximately $0.12 \%$ per month.
} The EPA Technical Assessment Report (EPA, 2016b) assumes an even slower scrappage rate. 
travel behavior for BEV is not the same as ICE vehicles. For PHEVs, only a fraction of the miles are electrified; in particular, the first miles of most trips. If long-range travel is reduced as the vehicle ages, this does not impact the eVMT and instead raises the effective utility factor. If, conversely, fewer trips are taken, but at a proportionally longer distance, this would lower eVMT.

Due to the effects of scrappage and vehicle travel effects, the impacts of PEV usage on gasoline displacement and electricity use may be overestimated. Combining the reduction in onroad vehicles with the reduction in mileage for older vehicles (both assuming equivalent reductions as ICE vehicles), the cumulative gasoline displacement and electricity use are potentially up to 5\% lower through November 2016.

Figure 11 shows an estimate of the battery capacity that is still on road and that which has been scrapped based on NHTSA estimates of scrappage rate for ICE vehicles (Lu, 2006). As of December 2017, only 2\% of PEVs (approximately 510 megawatt-hours) will have been scrapped based on historic trends.

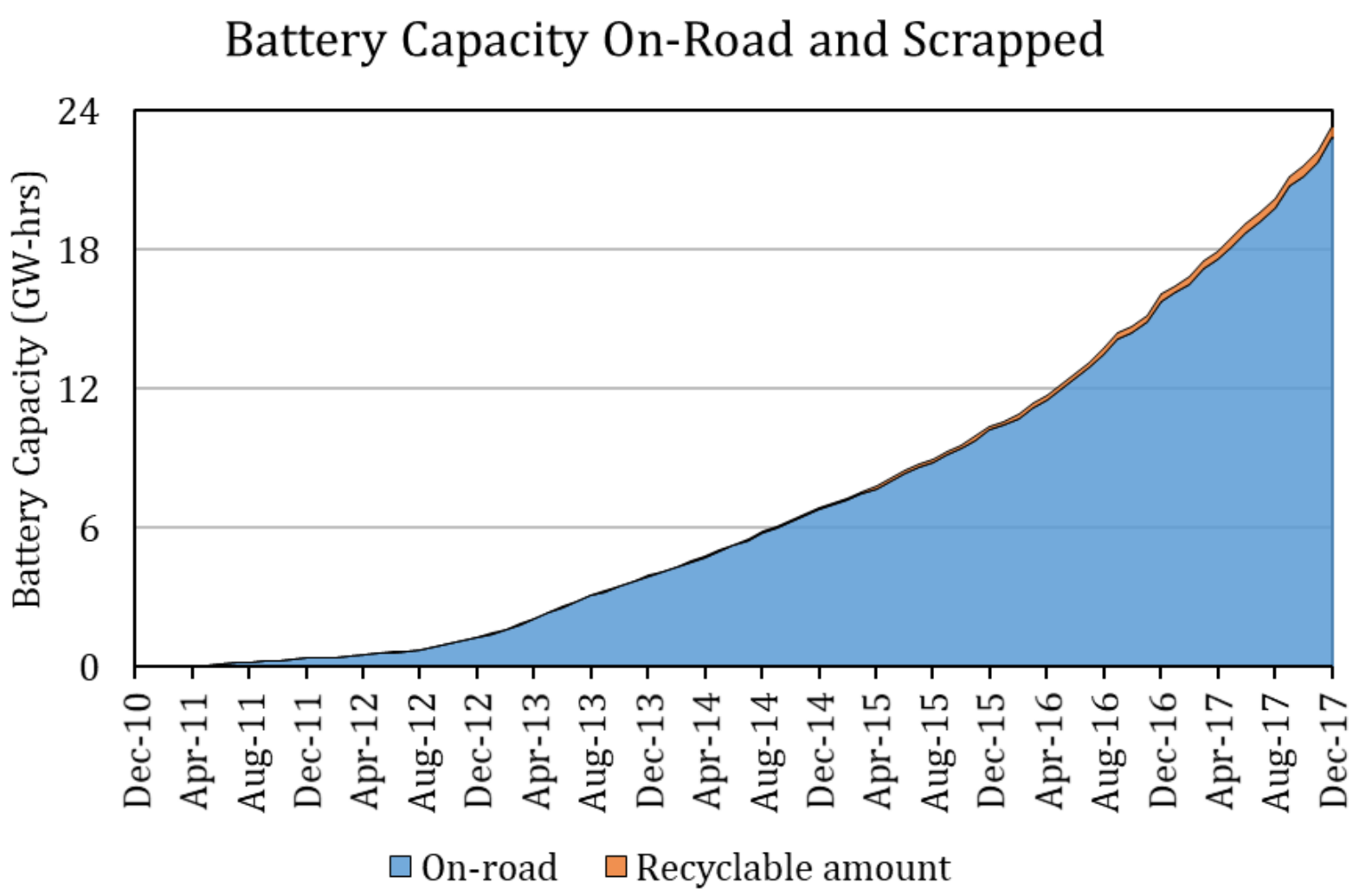

FIGURE 11 Cumulative PEV battery capacity remaining on road (blue) and scrapped (orange) by month 


\section{CONCLUSIONS}

Since the latest generation of light-duty plug-in electric vehicles have been available in the United States, over 750,000 PEVs have been sold, driving nearly 16 billion miles on electricity. These 16 billion eVMT consumed over 5.4 terawatt-hours of electricity while reducing gasoline consumption by 600 million gallons. Table 4 summarizes the total impacts of PEVs by year for eVMT, gasoline displacement, electricity consumption, and $\mathrm{CO}_{2}$ emissions reductions.

On average, electric vehicles have become more fuel efficient and have had longer allelectric driving ranges as technology has advanced. Most of the PEVs on the road were assembled in the United States. The market has begun to grow beyond the midsize and compact cars which were most common, with plug-in electric SUVs becoming more popular as models become available.

Some of the results shown in Table 4 depend on assumptions on traveler and purchase behavior. Exploring different ranges of driving behavior shows ranges of 12.0 to 19.5 billion eVMT, and 4.0 to 6.6 terawatt-hours of electricity consumption by PEVs. Using alternative choices for the ICE vehicle travel displaced by a PEV yields between 400 and 700 million gallons of gasoline displaced.

TABLE 4 Annual Sales of New PEVs, and Total Annual eVMT, Gasoline Reduction, Electricity Consumption, and $\mathrm{CO}_{2}$ Emissions Reduction by On-Road PEVs

\begin{tabular}{cccccc}
\hline Year & $\begin{array}{c}\text { PEV sales } \\
\text { (thousands) }\end{array}$ & $\begin{array}{c}\text { eVMT } \\
\text { (billion miles) }\end{array}$ & $\begin{array}{c}\text { Gasoline } \\
\text { reduction } \\
\text { (million gallons) }\end{array}$ & $\begin{array}{c}\text { Electricity } \\
\text { consumption } \\
\text { (gigawatt-hours) }\end{array}$ & $\begin{array}{c}\mathrm{CO}_{2} \text { emissions } \\
\text { reduction } \\
\text { (million metric tons) }\end{array}$ \\
\hline 2011 & 18 & 0.1 & 3 & 20 & 0.01 \\
2012 & 53 & 0.3 & 12 & 110 & 0.05 \\
2013 & 97 & 1.0 & 36 & 320 & 0.16 \\
2014 & 119 & 1.9 & 70 & 630 & 0.30 \\
2015 & 114 & 2.9 & 110 & 970 & 0.47 \\
2016 & 160 & 4.1 & 160 & 1,400 & 0.68 \\
2017 & 196 & 5.8 & 220 & 1,900 & 0.93 \\
Total & $\mathbf{7 5 7}$ & $\mathbf{1 6 . 0}$ & $\mathbf{6 0 0}$ & $\mathbf{5 , 4 0 0}$ & $\mathbf{2 . 6 0}$ \\
\hline
\end{tabular}


This page intentionally left blank. 


\section{APPENDIX A: UTILITY FACTORS AND TRAVEL BEHAVIOR}

The utility factor for PHEVs in this report comes from the Society of Automotive Engineers (SAE) J2841 standard, for "multi-day individual" vehicles (SAE, 2010). This quantity depends on driving behavior.

Figure 12 shows the utility factor for different driving characteristics. The Fleet Utility Factor (FUF) in blue and the Multi-Day Individual Utility Factor (MDIUF) in orange are meant to be representative of shared and privately-owned vehicles in the United States, respectively. Also shown are the World harmonized Light vehicles Test Procedure (WLTP) estimates of utility factors for Europe and Japan, as proposed (UNECE, 2017). The utility factor in the United States is lower than in Europe and Japan, due to the propensity for more long-range trips and fewer short-range trips in the United States. The baseline for this study is the MDIUF, which mostly closely approximates driving behavior of PHEV owners in the United States. Table 5 shows the impacts of using alternative utility factors for estimation.

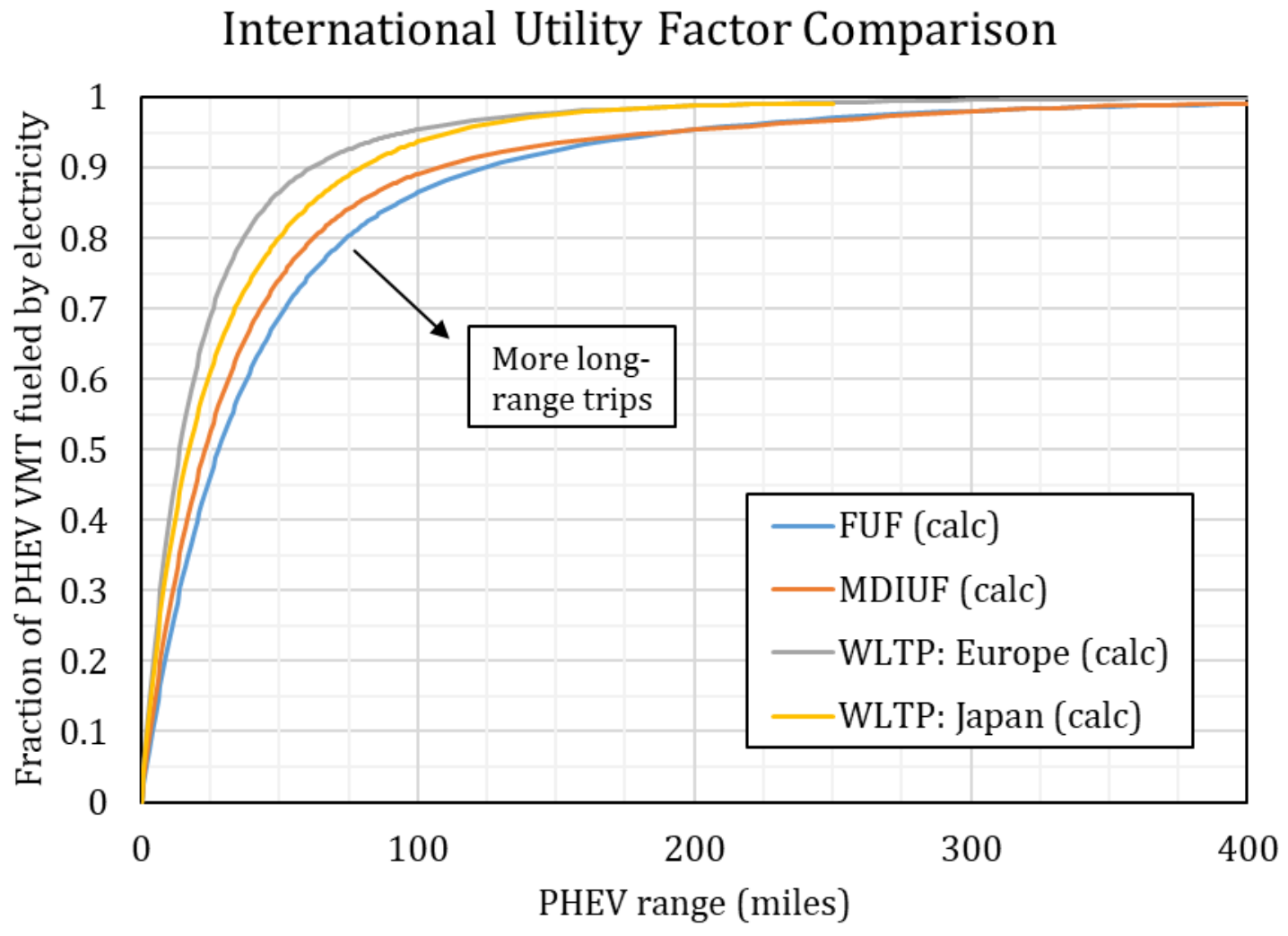

FIGURE 12 Comparison of PHEV utility factor from SAE and WLTP 
TABLE 5 Comparison of eVMT for PEVs as a Function of Assumed Utility Factor

\begin{tabular}{lcc}
\hline \multicolumn{1}{c}{ Utility Factor } & $\begin{array}{c}\text { eVMT } \\
\text { (billion miles) }\end{array}$ & $\begin{array}{c}\text { Electricity consumption } \\
\text { (Terawatt-hours) }\end{array}$ \\
\hline MDIUF [baseline] & 16.0 & 5.38 \\
FUF & $15.0(-5.9 \%)$ & $5.06(-6.0 \%)$ \\
WLTP (Japan) & $17.4(+8.8 \%)$ & $5.87(+8.9 \%)$ \\
WLTP (Europe) & $18.5(+15.7 \%)$ & $6.24(+15.9 \%)$ \\
\hline
\end{tabular}

Figure 13 shows the annual eVMT for PEVs as a function of all-electric range, assuming a baseline of 13,500 total miles, using the MDIUF utility factor for PHEVs in red. A further reduction of $15 \%$ to represent $\mathrm{BEV}$ travel is shown in purple, while squaring the (MDIUF) utility factor to represent BEV travel is shown in green. On-road data examining the driving characteristics of PEVs collected by the California Air Resources Board, Idaho National Laboratory, and the University of California at Davis are overlaid (CARB, 2017a; CARB, 2017b; Carlson, 2015; Nicholas et al., 2017; Plötz et al., 2017). For a given all-electric range, there is a wide spread of travel behavior, showing the uncertainty in estimating traveler behavior.

Annual eVMT (on-road comparison)

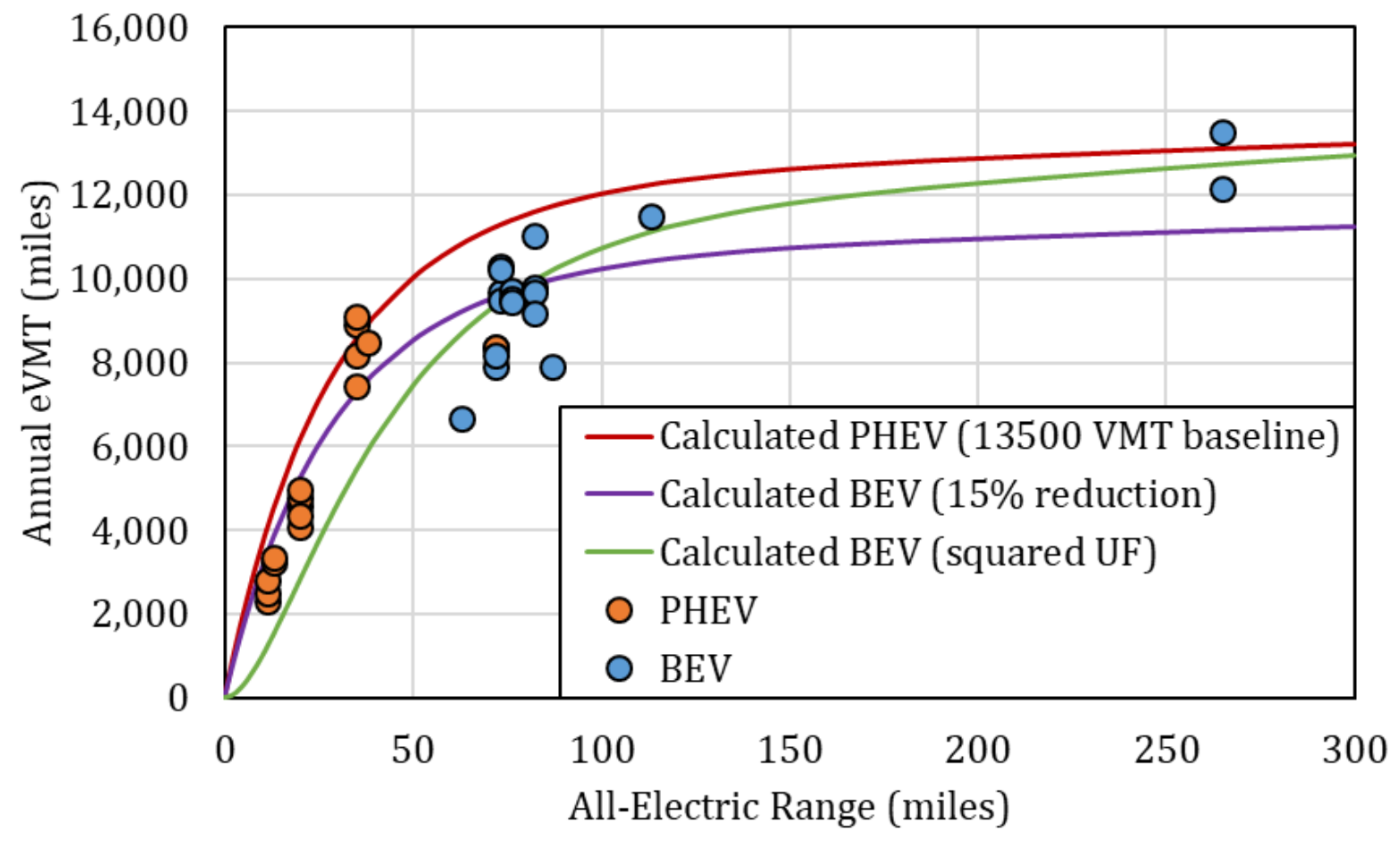

FIGURE 13 Comparison of effective utility factor for PHEVs and BEVs and on-road data 


\section{APPENDIX B: COMPARISON WITH OTHER REPORTS}

This report finds general, though not exact, agreement with other publications and press releases.

General Motors (GM) has published press releases about eVMT milestones for the Chevrolet Volt and Bolt (GM, 2016; GM, 2017). These have been about $40 \%$ lower than calculated in this report, though the utility factor is very similar, implying a much lower total VMT by these vehicles than assumed here. In a separate technical study, GM also collected 667 million miles of driving data for Chevrolet Volts between October 2013 and September 2014 (Duhon et al., 2015). 74\% of this was driven electrically (494 million eVMT). This compares well with the value in this study of 536 million eVMT, especially since the number of vehicles in the study was approximately $3-10 \%$ less than the number of vehicles sold through that time, likely due to a combination of drivers opting out of OnStar data collection and a small fraction of vehicles being scrapped.

Ford has claimed 610 million eVMT for all of its PEVs through December 2015. This compares with 555 million eVMT calculated here, though it includes energy regained from regenerative braking in this total (Voelcker, 2016).

Tesla has shared total fleet milestones as well, reaching 5 billion miles in July 2017, though these values include all worldwide use (Lambert, 2016; Lambert, 2017). Multiple sources estimate that 55\% of Tesla sales have been in the United States, through 2017 (EV Volumes, 2017; Kane, 2017; Pontes, 2017). This report finds 2.7 billion miles in the United States for the Model S and Model X through June 2017; attributing 55\% of Tesla's reported eVMT to the United States yields 2.75 billion miles, within $1 \%$ of this report.

Nissan has also published press releases about worldwide eVMT for the Nissan Leaf (Nissan, 2016). These worldwide values of eVMT (3 billion eVMT worldwide through 2016) are lower than the values for the United States alone estimated here. The cause of this discrepancy is not known. According to EV Volumes, which tracks worldwide PEV sales, only $40 \%$ of Nissan Leafs were sold in the United States between 2013 and 2017 (EV Volumes, 2017). The assumed annual mileage for a Nissan Leaf (for MY2010-13) as described in Appendix A is very close to the average on-road mileage found in by the California Air Resources Board, Idaho National Laboratory, and the University of California at Davis (CARB, 2017a; CARB, 2017b; Carlson, 2015; Nicholas et al., 2017).

With a similar methodology for estimating eVMT, PlugLess Power estimated 10.7 billion eVMT through February 2017, as compared to 11.1 billion in this analysis (Yamauchi, 2017). The largest difference between these two reports is that PlugLess used the specific values shown in Figure 13 for each vehicle, rather than using a general formula for the utility factor. For many vehicles, the two reports give similar total eVMT, though this report generally estimates a higher eVMT for short-range PHEVs than PlugLess does. 
Navigant Research published a report estimating the total electricity consumption and gasoline displacement from 2011 through 2014 (Shepard and Purcell, 2016). Over this timeframe, they estimated 98 million gallons of gasoline displacement and just over $1 \mathrm{TWh}$ of electricity consumption. For comparison, the present analysis finds $1.1 \mathrm{TWh}$ of electricity consumption and 120 million gallons of gasoline displacement over the same time, approximately 5-20\% higher than Navigant found. 


\section{REFERENCES}

ANL (Argonne National Laboratory), 2018. Light Duty Electric Drive Vehicles Monthly Sales Update. Accessed January 8, 2018. https://www.anl.gov/energy-systems/project/light-dutyelectric-drive-vehicles-monthly-sales-updates

CARB (California Air Resources Board), 2017a. California's Advanced Clean Cars Midterm Review, Appendix G: Plug-in Electric Vehicle In-Use and Charging Data Analysis. January 18, 2017. https://www.arb.ca.gov/msprog/acc/mtr/appendix_g.pdf

CARB (California Air Resources Board), 2017b. California's Advanced Clean Cars Midterm Review, Appendix I: Alternative Credits for Zero Emission Vehicles and Plug-in Hybrid Electric Vehicles. January 18, 2017. https://www.arb.ca.gov/msprog/acc/mtr/appendix_i.pdf

Carlson, Barney, 2015. Electric Vehicle Mile Traveled (eVMT): On-road Results and Analysis. Report INL/MIS-15-34807. http://energy.gov/sites/prod/files/2015/07/f24/vss171_carlson_2015_p.pdf

Chung, Donald, Emma Elgqvist, and Shriram Santhanagopalan, 2015. Automotive Lithium-ion Battery (LIB) Supply Chain and U.S. Competiveness Considerations. Report NREL/PR-6A5063354. https://www.nrel.gov/docs/fy15osti/63354.pdf

Chung, Donald, Emma Elgqvist, and Shriram Santhanagopalan, 2016. Automotive Lithium-ion Cell Manufacturing: Regional Cost Structures and Supply Chain Considerations. Report NREL/TP-6A20-66086. https://www.nrel.gov/docs/fy16osti/66086.pdf

Cobb, Jeff, 2018. “December 2018 Dashboard.” HybridCars, January 4, 2018.

http://www.hybridcars.com/december-2017-dashboard/

Cole, Jay, 2017. "19,130 BMW i3 REx Recalled In US Due To Fire Risk... Thanks To Its Gas Extender." Inside EVs, Feburary 18, 2017. http://insideevs.com/bmw-i3-rex-recalled-for-firerisk-thanks-to-its-gas-extender/

DOE (U.S. Department of Energy), 2016a. California Had the Highest Concentration of Plugin Vehicles Relative to Population in 2015. August 1, 2016.

https://energy.gov/eere/vehicles/fact-936-august-1-2016-california-had-highest-concentrationplug-vehicles-relative

DOE (U.S. Department of Energy), 2016b. Total Battery Capacity of all Plug-in Electric Vehicles Sold Increased from 2014 to 2015. August 8, 2016. https://energy.gov/eere/vehicles/fact-937-august-8-2016-total-battery-capacity-all-plugelectric-vehicles-sold 
DOE (U.S. Department of Energy), 2017. Motor Gasoline Is Most Common Petroleum Product from U.S. Refineries. February 13, 2017. https://energy.gov/eere/vehicles/fact-964february-13-2017-motor-gasoline-most-common-petroleum-product-us-refineries

DOE and EPA (U.S. Department of Energy and Environmental Protection Agency), 2018. FuelEconomy.gov. Accessed January 7, 2018. http://fueleconomy.gov/

Duhon, Aimee N., Kris S. Sevel, Steven A. Tarnowsky, and Peter J. Savagian, 2015. Chevrolet Volt Electric Utilization. SAE Int. J. Alt. Power. 4(2):2015, doi:10.4271/2015-01-1164. http://papers.sae.org/2015-01-1164/

EEI (Edison Electric Institute), 2017. Plug-in Electric Vehicle Sales Forecast Through 2025 and the Charging Infrastructure Required. Prepared by Adam Cooper and Kellen Schefter, June 2017.

http://www.edisonfoundation.net/iei/publications/Documents/IEI_EEI\%20PEV\%20Sales\%20a nd\%20Infrastructure \%20thru\%202025_FINAL\%20\%282\%29.pdf

EIA (Energy Information Administration), 2017. Monthly Energy Review. Accessed January 7, 2018. https://www.eia.gov/totalenergy/data/monthly/

Elgowainy, Amgad, Jeongwoo Han, Jacob Ward, Fred Joseck, David Gohlke, Alicia Lindauer, Todd Ramsden, Mary Biddy, Marcus Alexander, Steven Barnhart, Ian Sutherland, Laura Verduzco, Timothy J. Wallington, 2016. Cradle-to-Grave Lifecycle Analysis of U.S. LightDuty Vehicle-Fuel Pathways: A Greenhouse Gas Emissions and Economic Assessment of Current (2015) and Future (2025-2030) Technologies. Report ANL/ESD-16/7. https://greet.es.anl.gov/publication-c2g-2016-report

EPA and DOT (U.S. Environmental Protection Agency and Department of Transportation), 2010. Light-Duty Vehicle Greenhouse Gas Emission Standards and Corporate Average Fuel Economy Standards; Final Rule. Federal Register, Vol. 75, no. 88, pg. 25324. May 7, 2010. https://www.gpo.gov/fdsys/pkg/FR-2010-05-07/pdf/2010-8159.pdf

EPA (U.S. Environmental Protection Agency), 2011. New Fuel Economy and Environment Labels for a New Generation of Vehicles. Report EPA-420-F-11-017. https://nepis.epa.gov/Exe/ZyPURL.cgi?Dockey=P100BAV0.TXT

EPA (U.S. Environmental Protection Agency), 2016a. Light-Duty Automotive Technology, Carbon Dioxide Emissions, and Fuel Economy Trends: 1975 through 2016. Report EPA-420R-16-010. https://www.epa.gov/fueleconomy/trends-report

EPA (U.S. Environmental Protection Agency), 2016b. Midterm Evaluation of Light-Duty Vehicle Greenhouse Gas Emission Standards and Corporate Average Fuel Economy Standards for Model Years 2022-2025. July, 2016. https://nepis.epa.gov/Exe/ZyPDF.cgi/P100OXEO.PDF?Dockey=P100OXEO.PDF 
EPA (U.S. Environmental Protection Agency), 2017. eGrid 2014 Summary Tables. February 27, 2017. https://www.epa.gov/energy/egrid-2014-summary-tables

EV Volumes, 2017. The Electric Vehicle World Sales Database. Accessed January 7, 2018. http://www.ev-volumes.com

FHWA (Federal Highway Administration), 2017. Highway Statistics 2016: Annual Vehicle Distance Traveled in Miles and Related Data - 2016. December 2017. https://www.fhwa.dot.gov/policyinformation/statistics/2016/vm1.cfm

GM (General Motors), 2016. Chevrolet Volt Achieves 100,000 Sales in the United States. August 1, 2016.

http://media.chevrolet.com/media/us/en/chevrolet/home.detail.html/content/Pages/news/us/en/ 2016/aug/080116-volt.html

GM (General Motors), 2017. Bolt EV Owners Drive 4.5 Million Miles. April 25, 2017. http://media.chevrolet.com/media/us/en/chevrolet/news.detail.html/content/Pages/news/us/en/2 $\underline{\text { 017/apr/0425-boltev.html }}$

Inside EVs, 2018. Monthly Plug-In Sales Scorecard. Accessed January 8, 2018. http://insideevs.com/monthly-plug-in-sales-scorecard/

Kane, Mark, 2017. "Tesla Has Delivered More Than 250,000 EVs, 55\% In The U.S." Inside EVs, October 4, 2017. https://insideevs.com/tesla-has-delivered-more-than-250000-evs-55-inthe-u-s/

Kelly, Jarod, Qiang Dai, and Amgad Elgowainy, 2017. A Sales-Weighted Regional Analysis of Electric Vehicles in the United States. Presented at ISIE-ISSST 2017.

Lambert, Fred, 2016. “Tesla's global fleet reaches 3.5 billion electric miles - added 500 million in less than 3 months." Electrek, December 26, 2016.

https://electrek.co/2016/12/26/tesla-global-fleet-3-5-billion-miles/

Lambert, Fred, 2017. “Tesla's global fleet reaches over 5 billion electric miles driven ahead of Model 3 launch.” Electrek, July 12, 2017. https://electrek.co/2017/07/12/tesla-global-fleetelectric-miles-model-3-launch/

Lu, S., 2006. Vehicle Survivability and Travel Mileage Schedules. Report DOT HS 809952. https://crashstats.nhtsa.dot.gov/Api/Public/ViewPublication/809952

Nicholas, Michael A., Gil Tal, and Thomas S. Turrentine, 2017. Advanced Plug-in Electric Vehicle Travel and Charging Behavior Interim Report. Report UCD-ITS-RR-16-10. https://itspubs.ucdavis.edu/index.php/research/publications/publication-detail/?pub_id=2692 
Nissan, 2016. New Nissan Electric Café opens in Paris as the brand celebrates three billion EV kilometres worldwide. December 16, 2016. http://newsroom.nissan-europe.com/eu/en$\mathrm{gb} / \mathrm{media} /$ pressreleases/426166621/new-nissan-electric-cafe-opens-in-paris-as-the-brandcelebrates-three-billion-ev-kilometres-worldwid

Plötz, P., S. A. Funke, P. Jochem \& M. Wietschel, 2017. $\mathrm{CO}_{2}$ Mitigation Potential of Plug-in Hybrid Electric Vehicles larger than expected. Scientific Reports 7, 16493:2017. https://www.nature.com/articles/s41598-017-16684-9

Pontes, Jose, 2017. EV Sales: Tracking plug-in car sales all over the world. Accessed January 7, 2018. http://ev-sales.blogspot.com

SAE (Society of Automotive Engineers), 2010. Utility Factor Definitions for Plug-In Hybrid Electric Vehicles Using Travel Survey Data. Standard J2841_201009.

http://standards.sae.org/j2841_201009/

Santos, Adella, Nancy McGuckin, Hikari Yukiko Nakamoto, Danielle Gray, and Susan Liss, 2011. Summary of Travel Trends: 2009 National Household Travel Survey. Report FHWAPL-11-022. http://nhts.ornl.gov/2009/pub/stt.pdf

SEPA (Smart Electric Power Alliance), 2017. Utilities and Electric Vehicles: The Case for Managed Charging. https://sepapower.org/resource/ev-managed-charging/

Shepard, Scott and David Purcell, 2016. U.S. Electric Vehicle Energy Consumption: 20112014. https://www.osti.gov/scitech/biblio/1345812-electric-vehicle-energy-consumption

Smart, John Galloway and Shawn Douglas Salisbury, 2015. Plugged in: How Americans Charge Their Electric Vehicles. Report INL/EXT-15-35584.

https://avt.inl.gov/sites/default/files/pdf/arra/PluggedInSummaryReport.pdf

UNECE (United Nations Economic Commission for Europe, Inland Transport Committee, World Forum for Harmonization of Vehicle Regulations, Working Party on Pollution and Energy), 2017. Global technical regulation on Worldwide harmonized Light vehicles Test Procedures (WLTP). http://www.unece.org/fileadmin/DAM/trans/doc/2017/wp29grpe/ECETRANS-WP29-GRPE-2018-02e.pdf

Voelcker, John, 2016. "Ford Energi Plug-In Hybrids: Electric Miles Are Half Of Total." Green Car Reports, January 25, 2016. http://www.greencarreports.com/news/1101987 ford-energiplug-in-hybrids-electric-miles-are-half-of-total)

Yamauchi, Mia, 2017. Led by Volt, LEAF and Tesla Model S, EV Drivers in the U.S. have Racked up Well Over 10 Billion e-Miles Driven. Accessed January 7, 2018. https://www.pluglesspower.com/learn/led-volt-leaf-tesla-model-s-ev-drivers-u-s-racked-well10-billion-e-miles-driven/ 



\section{Argonne}

\section{Energy Systems Division}

9700 South Cass Avenue, Bldg. 362

Argonne, IL 60439-4854

www.anl.gov 